\title{
The sponge holobiont in a changing ocean: from microbes to ecosystems
}

\author{
L. Pita ${ }^{1 *+}\left(\mathbb{D}\right.$, L. Rix $^{1+}\left(\mathbb{D}\right.$, B. M. Slaby ${ }^{1}$ (D) A. Franke ${ }^{1}$ and U. Hentschel ${ }^{1,2}$ (D)
}

\begin{abstract}
The recognition that all macroorganisms live in symbiotic association with microbial communities has opened up a new field in biology. Animals, plants, and algae are now considered holobionts, complex ecosystems consisting of the host, the microbiota, and the interactions among them. Accordingly, ecological concepts can be applied to understand the host-derived and microbial processes that govern the dynamics of the interactive networks within the holobiont. In marine systems, holobionts are further integrated into larger and more complex communities and ecosystems, a concept referred to as "nested ecosystems." In this review, we discuss the concept of holobionts as dynamic ecosystems that interact at multiple scales and respond to environmental change. We focus on the symbiosis of sponges with their microbial communities - a symbiosis that has resulted in one of the most diverse and complex holobionts in the marine environment. In recent years, the field of sponge microbiology has remarkably advanced in terms of curated databases, standardized protocols, and information on the functions of the microbiota. Like a Russian doll, these microbial processes are translated into sponge holobiont functions that impact the surrounding ecosystem. For example, the sponge-associated microbial metabolisms, fueled by the high filtering capacity of the sponge host, substantially affect the biogeochemical cycling of key nutrients like carbon, nitrogen, and phosphorous. Since sponge holobionts are increasingly threatened by anthropogenic stressors that jeopardize the stability of the holobiont ecosystem, we discuss the link between environmental perturbations, dysbiosis, and sponge diseases. Experimental studies suggest that the microbial community composition is tightly linked to holobiont health, but whether dysbiosis is a cause or a consequence of holobiont collapse remains unresolved. Moreover, the potential role of the microbiome in mediating the capacity for holobionts to acclimate and adapt to environmental change is unknown. Future studies should aim to identify the mechanisms underlying holobiont dynamics at multiple scales, from the microbiome to the ecosystem, and develop management strategies to preserve the key functions provided by the sponge holobiont in our present and future oceans.
\end{abstract}

Keywords: Sponges, Holobiont, Health, Symbiosis, Microbiome, Nested ecosystems, Stress, Climate change, Dysbiosis, Disease

\section{Background}

Marine animals live and evolve in a sea of microbes. The ocean is the largest habitat on our planet and microbes are its most abundant inhabitants. These microorganisms (i.e., viruses, bacteria, archaea, microeukaryotes) play a key role in global biogeochemical cycles [1]; yet, scientists are only beginning to reveal their genomic and metabolic diversity [2]. Marine microbes exist not only in a planktonic state but also in symbiosis with

\footnotetext{
* Correspondence: Ipita@geomar.de

${ }^{\dagger}$ Equal contributors

${ }^{1}$ RD3 Marine Microbiology, GEOMAR Helmholtz Centre for Ocean Research, Kiel, Germany

Full list of author information is available at the end of the article
}

macroorganisms: animals, plants, and algae alike [3, 4]. The prevalence of these associations implies that multicellular organisms can no longer be considered as autonomous entities [5] but rather as holobionts (syn. "metaorganisms" [6]), encompassing the host plus its associated microbiota $[7,8]$. The microbial partners contribute to the nutrition [9], defense [10], immunity [11], and development [12] of the host; thereby collectively influencing its health and functioning.

The first approaches to define the holobiont consisted of characterizing the set of microbial taxa common to all individuals of a certain species, the core microbiota. Later definitions, enabled by massively increased 


\section{Box 1 Glossary}

Acclimatization: The capacity of a holobiont to adjust to a perturbation through host phenotypic plasticity or restructuring of the microbiome in order to reach a new stable state

Adaptation: A transgenerational process that enhances the fitness of the holobiont through transgenerational acclimatization, heritable microbial community changes, or host/symbiont evolution

Core microbiome: The set of microbial taxa which are consistently and stably prevalent in host individuals of the same species

Dysbiosis: The divergence of a symbiotic microbial community from the community found in healthy individuals

Disease: The impairment of normal function following perturbation or damage. May be, but is not necessarily, induced by a pathogenic microorganism

Functional convergence: In the holobiont context, symbiotic microbial communities with different evolutionary histories that have, via different but analogous pathways, converged upon similar functional solutions

Functional redundancy: The presence of several microbial taxa within an ecosystem or holobiont that perform the same functions, such that the loss of one particular taxon or a shift in the community diversity would not compromise ecosystem function

Holobiont health: A dynamic equilibrium that allows minor fluctuations in terms of diversity or functions to ensure the maintenance of symbiotic homeostasis

Microbiota: The assemblage of microorganisms present in a defined environment or host

Microbiome: The group of microbes, their genetic information, and the surrounding environmental conditions in a defined environment or host

Nested ecosystem: A smaller distinct ecosystem which is contained within and interacts with a larger ecosystem or series of successively larger ecosystems

Opportunistic: An organism that is capable of causing damage to a host under specific conditions, but may also exist as a commensal within the same host under normal conditions

Perturbation: A temporary or persistent change in biotic or abiotic conditions that leads to a response by an ecosystem or holobiont Resilience: The capacity of a system to recover its initial functional and taxonomical composition and return to an initial stable state following a perturbation

Resistance: The property of a system to remain unchanged and maintain at a stable state upon perturbation

Symbiosis (sensu De Bary): The close association of two or more organisms of a different species. This association may be mutualistic, commensal, or parasitic sequencing efforts, included the core set of functional genes that ensured homeostasis of the holobiont [13, 14]. However, holobiont functioning is not only determined by the processes carried out by the individual members, but also by the interactions among them. Consequently, holobionts can be regarded as complex ecosystems to which the concepts and methodologies from ecology can be applied to understand the drivers of holobiont stability [15-17]. Under this perspective, the holobiont represents a dynamic equilibrium characterized by two important properties: resistance (the ability to withstand perturbation unchanged) and resilience (the capacity to recover upon disturbance). This view contributes to understanding the dynamics of the microbial and host-related processes involved in maintaining a healthy holobiont [15-17] and its response to environmental change [18-20].

Moreover, the holobiont performs functions that cannot be accomplished by the partners separately. The microbiome provides essential functions to the host and together they mediate the interactions of the holobiont with the surrounding organismal community [5]. Through cascading effects, the microbiome can ultimately impact ecosystem health and functioning. One prominent example is the symbiosis between corals and their photosynthetic dinoflagellates (Symbiodinium spp.). By virtue of autotrophic $\mathrm{CO}_{2}$ fixation, Symbiodinium provide the necessary primary metabolism that enables corals to engineer the three-dimensional calcium carbonate structure that, ultimately, supports the entire reef ecosystem [21]. Conversely, coral bleaching resulting from the loss of dinoflagellate symbionts not only has severe consequences for coral health, but also has devastating effects on the entire coral reef ecosystem [22]. Therefore, an integrative approach that considers these different scales is needed to evaluate holobiont function within these nested ecosystems.

In this review, we will discuss how host- and microbial-mediated activities translate into the emerging functions of the sponge holobiont that impact the surrounding ecosystem, and how the holobiont is in turn affected by the anthropogenic pressures increasingly impacting marine ecosystems. Marine sponges (phylum Porifera) perfectly illustrate the idea of holobionts as ecosystems, given the exceptionally diverse microbial communities housed within them $[23,24]$. Sponges are a successful (>8000 species) and evolutionarily ancient phylum, their members being globally distributed and abundant within the benthic communities of a wide range of habitats $[25,26]$. Their sessile filter-feeding lifestyle constantly exposes them to the microbes in the seawater that form their primary food source; yet, they harbor distinct symbiotic microbial communities. Sponges influence ecosystem functioning by modifying 


\section{Box 2 The HMA-LMA dichotomy}

Sponges can be classified into two groups according to the abundance and density of microbes in their tissues. High microbial abundance (HMA) sponges harbor densities of microbes 2-4 orders of magnitude higher than low microbial abundance (LMA) sponges $[225,226]$. A recent publication made use of the Global Sponge Microbiome Project data to further investigate the microbial diversity features of HMA and LMA sponges at large scale by way of a machine learning [227]. HMA sponges harbor richer and more diverse microbial communities than LMA sponges [227] (although there are few exceptions to this pattern, e.g., [228]). Additionally, certain taxa (from phylum to 97\% OTU-level resolution) are significantly enriched in either one or the other group [227]. For example, LMA sponges are enriched in Proteobacteria and Cyanobacteria whereas HMA sponges are enriched in Chloroflexi, Acidobacteria, or Poribacteria, among others. Despite these differences in microbial diversity and abundance, the functional convergence of microbiome core functions appears to span the HMA-LMA dichotomy [31, 53]. However, differences in gene abundances between central metabolic functions of LMA and HMA microbial communities have been reported [64]. Interestingly, sponge species diverge in presenting one of these two microbial configurations, regardless of host phylogeny [226, 227]. It has been proposed that sponge morphology may be a determinant factor: HMA sponges have denser tissues with less-developed water channels compared with LMA sponges [226, 229, 230]. Still, the processes underlying this dichotomy remain unknown.

biotic and abiotic factors (reviewed in [27]). For example, they provide habitat for a wide range of fauna and play an important role in benthic-pelagic coupling due to their impressive filtering capacity [26, 28-30]. The field of sponge microbiology has consolidated in recent years as collaborative efforts have developed standardized protocols and curated databases on spongeassociated microbial diversity (i.e., the Global Sponge Microbiome Project) [23, 24]. Novel approaches, combined with state-of-the-art techniques, have begun to reveal the functions of the collective microbial community and individual symbiont groups [31-35]. One major finding is that many of the functional roles provided by sponges are indeed mediated by their associated microbes. The natural variability across sponge holobionts and environments, together with the possibility for lab experiments, opens up the opportunity to address the dynamics of these complex symbiotic systems [36]. It is therefore timely to scale up the marine sponge holobiont concept from the microbial to the ecosystem level, particularly in the context of health, disease, and response to anthropogenic pressures.

\section{The marine sponge holobiont Microbial core diversity}

The Global Sponge Microbiome Project, under the umbrella of the Earth Microbiome Project, is a recent collaborative initiative to assess the microbial diversity in sponges from around the world, following standardized protocols [23, 24]. Similar to the Human Microbiome Project [37], the main goal was to create a publicly available database that would enable comparative studies in order to discover common patterns and principles of sponge-associated microbial assemblies. The first comprehensive study [23], including 81 sponge species, revealed that the sponge microbiome spans at least 39 microbial phyla and candidate phyla (Fig. 1). The most dominant bacterial symbiont groups belong to the phyla Proteobacteria (mainly Gamma- and Alphaproteobacteria), Actinobacteria, Chloroflexi, Nitrospirae, Cyanobacteria, and candidatus phylum Poribacteria, while Thaumarchaea represents the dominant archaeal group [23, 24]. The microbial communities are species-specific, but composed of both generalist microbes that are detected in the majority of sponge species from diverse geographic regions, as well as specialists that are enriched in particular species but are rare or absent in most other species [23, 38]. A second sequencing effort has recently expanded this dataset to over 260 sponge species, yet, the overall patterns remain consistent [24].

In terms of community structure, complex hostassociated microbial communities are divided into a core microbiome (members that are highly prevalent in all host individuals of the same species) and a variable microbiome (members of the microbial community that are recovered only from some individuals or that vary in their relative abundance) [39]. Surveys along different environmental gradients (e.g., geographical distance [40], season [41, 42], depth [43], and habitat [44]) have consistently confirmed that sponges harbor species-specific and stable microbiomes at different prokaryotic taxonomic levels [45] and prevalence thresholds [46]. This stability is remarkable when compared with the dynamic turnover of bacterioplankton in the surrounding water, upon which sponges feed [41], and hints to the importance of host-related factors in shaping the core microbiome. However, there is also evidence that suggests that environmental conditions impact sponge-associated microbial diversity, particularly the variable fraction. For example, two sponge species that were able to colonize and proliferate in the acidified environment of a $\mathrm{CO}_{2}$ seep [47], harbored significantly higher relative numbers of symbiotic Synechococcus at the $\mathrm{CO}_{2}$ seep compared with specimens at control sites less than $500 \mathrm{~m}$ away. 


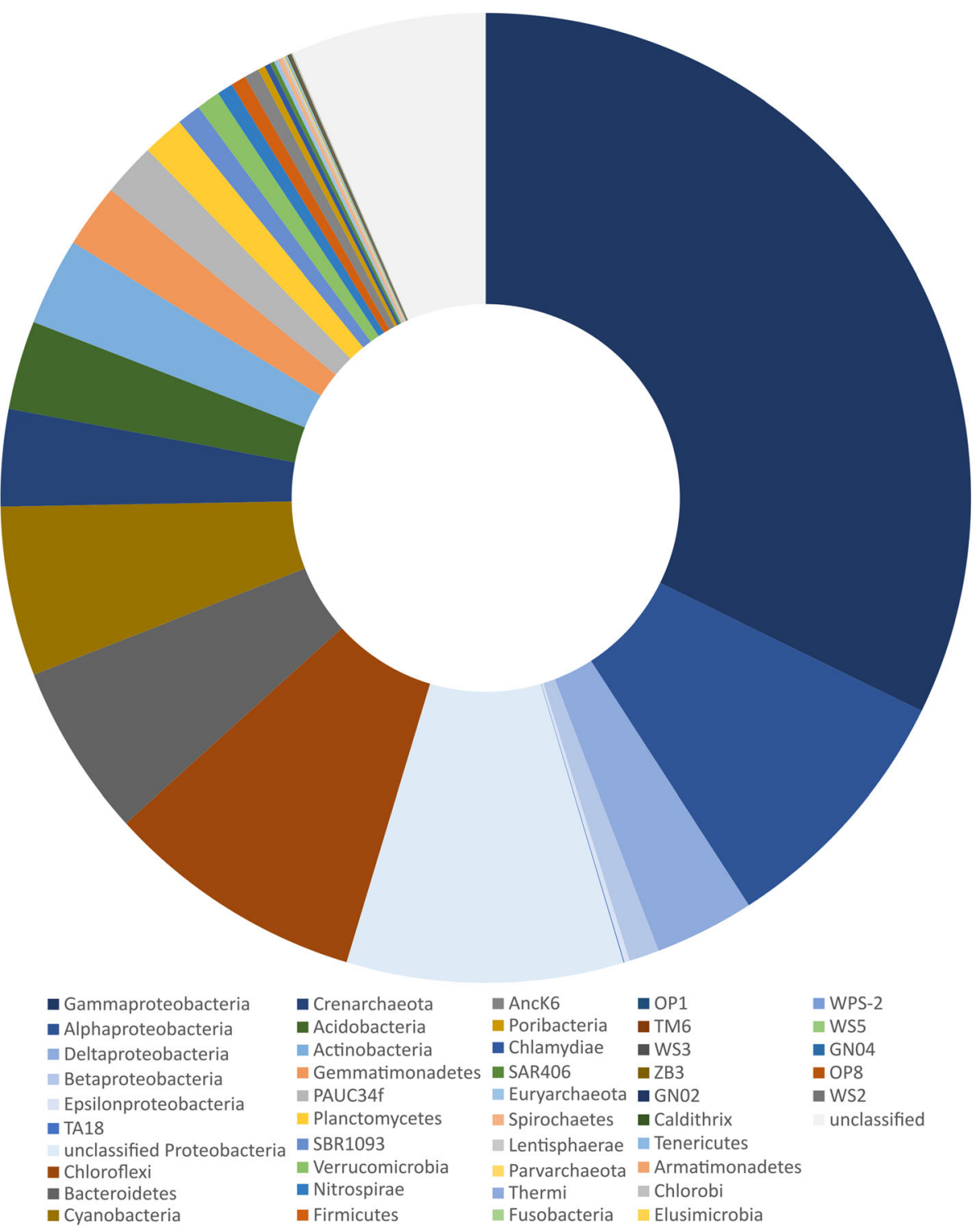

Fig. 1 Microbial OTU richness in sponge-associated microbial communities at phylum level. The Greengenes annotation of the representative sequences for sponge-associated OTUs detected by the Global Sponge Microbiome [23] was used to create this chart. A diversity of 43,034 OTUs from 39 classified microbial phyla (bacteria and archaea) was detected in the microbiomes of the 81 sponge species in this project [23]

Temporal variation, depth, and habitat type can also impact the composition of sponge-associated microbiota $[43,48,49]$. An additional driver of spongeassociated microbiota structure is the HMA-LMA dichotomy.

Microbe-microbe interactions within the holobiont can further affect the dynamics and stability of the symbiosis [50, 51]. Network and modeling analyses aim to disentangle the strength and nature (positive, negative, or neutral) of the interactions and predict their dynamics. Bacteria-bacteria network analysis of the core microbiota in different sponge species has revealed a low connective network with very few strong and many weak unidirectional interactions (i.e., amensalism $(-/ 0)$ and commensalism $(+/ 0)$ prevailed over cooperation $(+/+)$ and competition $(-/-))$ [23]. These findings are consistent with mathematical models that predict that weak and non-cooperative interactions help to stabilize highly diverse microbial communities, whereas cooperation yields instability in the long term by fueling positive feedbacks [52].

\section{Microbial core functions}

Since sponge symbionts remain largely uncultivable, culture-independent methodologies have been instrumental to gain genomic and thereby putative functional 
information on sponge symbionts. Indeed, a variety of metagenomic, metaproteomic, and metatranscriptomic sequencing approaches have been employed to elucidate the functions of the sponge microbiome [31, 53-56]. Single-cell genomics and metagenomic binning have obtained a number of individual symbiont genomes [33, 57-59]. Furthermore, novel visualization techniques have been developed and applied to test hypotheses derived from genomic data as well as gain valuable spatial information [34, 35].

Comparisons between metagenomes of spongeassociated and seawater microbial consortia have identified gene features enriched in sponge symbionts that might be relevant to the symbiosis $[31,53,60,61]$. These features have been found in the microbiomes of multiple sponge species from various geographic regions, but they are mediated by different microbial taxa and carried out by different, although analogous, pathways [53, 62]. This functional convergence hints to features that are necessary for microbial persistence in the host as well as holobiont success, and therefore can be considered core functions of the sponge microbiome [23, 31, 53, 62]. Beyond the housekeeping genes required for microbial life, we define core functions as the range of metabolic and defensive features that allow the sponge microbiota to colonize, interact with, and adapt to the host environment (Table 1). Metabolic features within the core functions include (a) the autotrophic and heterotrophic pathways for symbionts to utilize the nutrients available in the sponge host environment-either produced by the host itself or filtered in from the surrounding seawater-and (b) the pathways that directly contribute to the symbiotic relationship with the host. Defensive features include those that enable symbiont persistence within the sponge host. In addition, most studied sponge symbiont genomes lack genes encoding for flagella, which points to a non-motile existence within the mesohyl matrix $[33,61]$ (but see $[53,63]$ ).

Nitrogen is generally a limiting nutrient in the marine environment but is excreted in large quantities by the sponge host, which produces ammonia as a metabolic waste product. Consequently, it is not surprising that sponge symbionts are enriched in nitrogen metabolism genes [53, 64-66]. Ammonia oxidation is particularly prevalent and predominant $[53,62,64,67,68]$, but most major nitrogen cycling pathways occur, including both aerobic (e.g. nitrification, nitrogen fixation) and anaerobic (e.g., denitrification, anammox) processes [59, 64, 69-73]. The presence of anaerobic metabolism is likely facilitated by the fact that the sponge tissue can rapidly become anoxic during temporary cessation of sponge pumping [74-76].

A large part of the sponge microbiota relies on heterotrophic metabolism and uses nutrient sources derived from the seawater filtered by the sponge, as well as produced by the sponge host itself [77]. With respect to carbon metabolism, the degradation of complex carbohydrates appears to be a dominant feature in sponge symbioses and highlights the role of heterotrophy in these communities [32, 33]. For example, there is mounting evidence that the symbionts also feed on sponge cell biomass and components of the sponge extracellular matrix [32, 33, 78]. The core functions of the microbiota also encompass metabolic features that potentially benefit the host. Sponge symbionts are enriched in genes related to the synthesis of vitamins, such as vitamin $B_{1}$ and vitamin $B_{12}[31,53,72,79]$, suggesting the symbionts may satisfy the host's demand for these essential vitamins. For example, a recent holobiont transcriptome study showed that the sponge microbiome was enriched in gene functions related to anabolic pathways of several amino acids and vitamins for which the host Xestospongia muta expressed only catabolic reactions [72]. The diverse and abundant range of membrane transporters (e.g., ABC-type transporters) encoded by the sponge microbiome provides mechanisms to facilitate these putative metabolic exchanges [53]. In addition, microbial symbionts have been identified as the source of certain secondary metabolites that constitute the chemical defense of the sponge holobiont [79, 80].

In order to persist within sponges, microbes must avoid phagocytosis by the host cells. Eukaryotic-like protein domains (ELPs), such as ankyrin repeat proteins, tetratricopeptide repeat proteins, and leucine-rich repeat proteins, were found to be highly enriched in and also expressed by sponge symbionts [31, 54, 81-83]. ELPs mediate protein-protein interactions and are hypothesized to play a role in the evasion of phagocytosis [81]. Another possible strategy has been found in the cyanobacterial symbiont "Candidatus Synechococcus spongiarum" that lacks a lipopolysaccharide (LPS) antigen [83]. This modification of the LPS in the symbiont vs free-living Synechococcus could represent a mechanism for the sponge host to discriminate between food and symbiotic bacteria [84].

Additional defensive core functions relate to protection and stress response (e.g., stress proteins, restriction modification, toxin-antitoxin systems, and clustered regularly interspaced short palindromic repeats CRISPRs). These defensive functions likely shield sponge symbionts against incoming foreign DNA, pathogens, and toxins to which they are exposed due to the pumping activity of the host [31, 33, 61]. Interestingly, elevated GC content and larger genome sizes were observed in sponge metagenomes in comparison to seawater metagenomes [61]. The larger genome sizes are attributed to higher levels of horizontal gene transfer (HGT) within the sponge host than in the seawater 
Table 1 Core functions of the sponge microbiome

\begin{tabular}{|c|c|c|c|}
\hline & Core function & Interpretation & Reference \\
\hline \multirow[t]{6}{*}{ Metabolic features } & $\begin{array}{l}\text { Nitrogen metabolism with } \\
\text { emphasis on ammonia oxidation }\end{array}$ & $\begin{array}{l}\text { Utilization of environmental and } \\
\text { host-derived nutrients }\end{array}$ & Reviewed in [77] \\
\hline & $\begin{array}{l}\text { Carbon metabolism with } \\
\text { emphasis on } \\
\text { complex carbohydrates }\end{array}$ & $\begin{array}{l}\text { Utilization of environmental and } \\
\text { host-derived nutrients }\end{array}$ & {$[32,33]$} \\
\hline & $\begin{array}{l}\text { Nitrogen and carbon } \\
\text { metabolism } \\
\text { utilizing creatinine }\end{array}$ & $\begin{array}{l}\text { Utilization of environmental and } \\
\text { host-derived nutrients }\end{array}$ & {$[35,53]$} \\
\hline & $\begin{array}{l}\text { Vitamin synthesis } \\
\text { (especially thiamine and vitamin B12) }\end{array}$ & $\begin{array}{l}\text { Overproduction of vitamins that } \\
\text { are then utilized by the sponge host }\end{array}$ & {$[31,53,72]$} \\
\hline & Secondary metabolism & $\begin{array}{l}\text { Microbe-microbe interaction, } \\
\text { defense of the holobiont }\end{array}$ & \\
\hline & Carnitine (vitamin BT) utilization & Utilization of host-derived component & {$[33]$} \\
\hline \multirow[t]{5}{*}{ Defense features } & CRISPR-Cas systems & Defense against viruses/phages & {$[31,33,61]$} \\
\hline & Toxin-antitoxin systems & Defense against foreign DNA & {$[31,33,61]$} \\
\hline & Restriction modification systems & Defense against foreign DNA & {$[31,33,61]$} \\
\hline & Eukaryotic-like protein domains & phagocytosis evasion & {$[31,54,81-83]$} \\
\hline & $\begin{array}{l}\text { Modifications of the } \\
\text { lipopolysaccharide }\end{array}$ & phagocytosis evasion & {$[83,84]$} \\
\hline Other & $\begin{array}{l}\text { Mobile genetic elements } \\
\text { and transposases }\end{array}$ & $\begin{array}{l}\text { Increased levels of horizontal } \\
\text { gene transfer }\end{array}$ & {$[31,53,61,85]$} \\
\hline
\end{tabular}

environment and adaptations to the more variable and nutrient-rich sponge-associated environment [61]. The hypothesis of increased levels of HGT is supported by the high number of mobile genetic elements found in the genomic repertoires of sponge symbionts, as well as transposases necessary for genetic transfer, which likely played a role in the evolutionary adaptation of the sponge microbiota to the symbiotic lifestyle $[31,53,85]$.

To elucidate their role within the community, single members of the sponge microbiome have been studied individually and revealed examples of specialization. For example, metagenomic binning revealed three symbiont guilds in Aplysina aerophoba displaying metabolic specialization to different substrates [33]. Each guild was composed of a phylogenetically diverse group of symbiont members, suggesting independent evolution to different micro-niches within the sponge extracellular matrix. A remarkable example of a function carried out by a specific member of the microbiota is that of "Candidatus Entotheonella factor," which produces almost all polyketides and peptide families that were previously attributed to synthesis by the host sponge, Theonella swinhoei [79]. This example is exceptional in that a specific bacterial clade associates with a specific sponge host and endows the holobiont with defensive capacities. Moreover, a recent study merging metagenomic binning, metatranscriptomics and visualization techniques has revealed tightly interlinked metabolic pathways between members of the holobiont of the Cymbastella concentrica; two proteobacteria, a thaumarchaeon and a diatom
[35]. The thaumarchaeon and a Nitrospira bacterium are hypothesized to be coupled in their nitrification activity, producing nitrate that is subsequently used by the Phyllobacteriaceae bacterium and the diatom [35].

Studies on single symbiont groups highlight the potential for high levels of specialization and interdependency within sponge holobionts. They also complement community level approaches by linking diversity with function. In these complex ecosystems, it is particularly challenging to identify which taxa contribute to each functional trait and the degrees of redundancy of particular functions remains unknown. Future studies should validate the genomic information presented here with a focus on those functions directly involved in the symbiotic interaction. In this direction, further efforts for cultivation would provide valuable insight into the chemical characterization and environment-regulated activity of target symbionts.

\section{The sponge host}

Sponge hosts may be viewed as ecosystem engineers [52], since they provide a certain habitat that selects for the presence and persistence of certain microbes, but not others. They also control their microbial residents by specifically recognizing and differentiating between foreign and symbiotic microbes $[84,86]$, likely via the innate immune system. The innate immune system, traditionally investigated in the context of pathogenesis, allows colonization and long-term maintenance of the symbiosis (reviewed in [87]). Pattern recognition 
receptors (PRRs) sense microbial ligands, but the activated response is context-dependent: symbiont-derived signals promote homeostasis, whereas pathogens induce an inflammatory response.

The underlying molecular mechanisms of microbial recognition by sponges remain elusive due to experimental limitations [36]. However, high-throughput sequencing data revealed that sponges harbor a complex genomic repertoire encoding a broad spectrum of immune receptors (including Toll- and NOD-like receptors and scavenger receptor cysteine-rich (SRCR) family members) [60, 88, 89], for which the role in responding to microbes is beginning to be elucidated [90, 91]. For example, the sponge Petrosia ficiformis displayed an increased expression of a gene containing the conserved SRCR domain when living in symbiosis with a cyanobacterium, in comparison to the aposymbiotic status [90]. Also, components of the Tolllike receptor pathway such as MyD88 were involved in the response to microbial signals in different species [91, 92]. In a recent experiment on juvenile Amphimedon queenslandica [91], bacterial encounter involved regulation of SRCR-containing genes, but the downstream response differed depending on the origin of the bacteria. In particular, the transcription factors FoxO and $\mathrm{NFk} \beta$ were upregulated upon exposure to own symbionts, but not to a bacterial fraction from another sponge species. These new findings suggest that sponges actively recognize and discriminate microbes via immune signaling. Host recognition of the microbiota also acts on symbiont acquisition: the host promotes certain microbial species through vertical transmission from adult to progeny or by direct recognition and uptake of symbionts from the environmental pool. In sponges, both modes of microbial transmission likely occur [93-98], yet the underlying mechanisms of host-microbe crosstalk remain to be identified. Hostrelated processes would impose a means to maintain specific microbiomes, but it is likely that host-independent process (e.g., stochasticity) also play a role, particularly in the environmentally acquired microbial fraction [18].

\section{From microbes to ecosystems}

Highly diverse holobionts can be considered as complex ecosystems $[15,20,52]$ in which the actions and interactions of the various members shape the overall functioning of the holobiont. These individual ecosystems in turn interact with and influence neighboring holobionts, such that they are further integrated into larger communities and ecosystems that interact at successively larger scales [5]. Consequently, the actions of a single member of the microbiota can exert an effect far beyond that of the holobiont. Key examples of this concept of "nested ecosystems" are the chemoautotrophic symbionts associated with hydrothermal vent animals or the phototrophic symbionts associated with reef-building corals that supply nutrition for their hosts who in turn support the larger communities in these unique ecosystems $[5,22$, 99]. The sponge microbiome provides a number of functions that are amplified by host activity and through cascading effects mediate the functioning of the sponge holobiont at the community and ecosystem level. Here, we provide five key examples where such microbial-mediated functions scale up to influence community structure and contribute to ecosystem primary productivity, biogeochemical nutrient cycling, and benthic food webs (Fig. 2).

\section{Photosynthesis}

Sponges can host photoautotrophic symbionts that not only contribute to host nutrition through the translocation of photosynthetically fixed carbon and nitrogen [100-102], but also contribute to ecosystem primary productivity [103]. In species hosting photosymbionts, these symbionts can potentially supply more than $50 \%$ of the holobiont's energy requirements [102-104]. Symbiont contribution to host nutrition appears to be highly variable as only some sponges receive a nutritional benefit from their photosymbionts, and reduced photosynthetic capacity does not always correspond with a reduction in host growth [102, 105-107]. Nevertheless, photosynthetic symbionts enable sponge holobionts to contribute to the gross primary productivity that supports the entire ecosystem [108]. Similarly, evidence for chemoautotrophy [109-111] suggests that chemoautotrophic sponge holobionts may contribute to ecosystem primary productivity, particularly in deep-sea environments, such as hydrothermal vents and cold seeps [68, 111-113], where such symbioses are essential for supporting life in these extreme environments [99].

\section{The sponge loop}

The assimilation of dissolved organic matter (DOM) by sponge holobionts facilitates DOM cycling in benthic habitats with cascading effects on marine food webs [29]. Microbes contribute to the assimilation of DOM by the sponge holobiont $[29,114,115]$, which can account for up to $\sim 90 \%$ of the holobiont's total heterotrophic carbon uptake [116-122]. In addition to providing an important food source for the holobiont, DOM uptake by sponges has been proposed to play a key role in DOM cycling within tropical and deep-sea coral reefs via a pathway termed the "sponge loop" [29, 114]. By rapidly taking up the DOM released by primary producers and converting it into particulate organic matter (POM) in the form of detritus, sponges transform DOM into a food source that is more readily available to other benthic reef fauna $[29,115,123,124]$ (Fig. 2). Similar to the microbial loop $[1,125]$, the sponge loop therefore enables the energy and nutrients in DOM to be retained and recycled within reef food webs. Although exact 


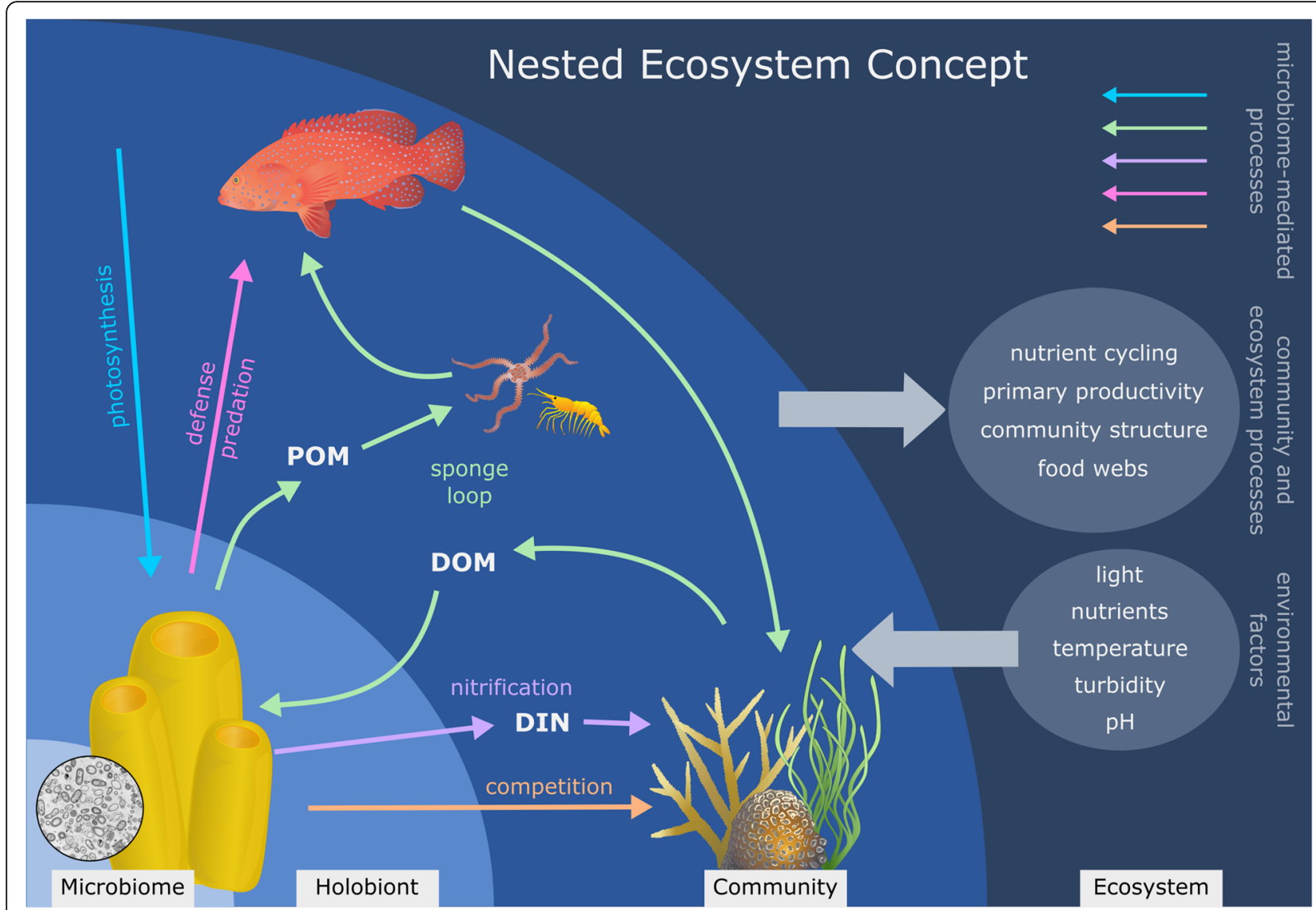

Fig. 2 The sponge holobiont as an example of the concept of nested ecosystems. Key functions carried out by the microbiome (colored arrows) influence holobiont functioning and, through cascading effects, subsequently influence community structure and ecosystem functioning. Environmental factors act at multiple scales to alter microbiome, holobiont, community, and ecosystem scale processes. Thus, factors that alter microbiome functioning can lead to changes at the holobiont, community, or even ecosystem level and vice versa, illustrating the necessity of considering multiple scales when evaluating functioning in nested ecosystems. DOM, dissolved organic matter; POM, particulate organic matter; DIN, dissolved inorganic nitrogen

quantification of DOM cycling by the sponge loop is lacking, DOM uptake by cryptic sponges in the Caribbean and Indo-Pacific is estimated to be on the same order of magnitude as gross reef primary productivity and may even exceed DOM cycling by the microbial loop [29, 126]. Thus, by acting through the sponge loop, the sponge microbiome may play an important role in driving DOM cycling at the ecosystem level, as well as facilitating energy transfer through reef food webs (Fig. 2).

\section{Inorganic nutrient cycling: nitrogen and phosphorous}

Sponge holobionts play an important role in the biogeochemical cycling of nitrogen-one of the main nutrients limiting primary productivity in the marine environment $[30,127]$. This capacity for nitrogen cycling is intimately linked to nitrogen transformations carried out by the sponge microbiome $[72,128]$. Nitrification via ammonia and nitrite oxidization is particularly prevalent and may benefit the host through removal of the large quantities of host-excreted ammonia [129]. Whether a sponge hosts large numbers of highly active nitrifying microbes dictates if it releases nitrogen primarily as ammonia or nitrate $[62,119,127]$. Moreover, since the sponge microbiome can simultaneously perform competing nitrogen cycling pathways (e.g., nitrification and denitrification) $[69,72,75]$, the relative activities of different members of the microbiome can further influence whether the holobiont acts as a net source or sink of bioavailable nitrogen [101, 128]. In oligotrophic marine environments like coral reefs, nitrogen can be released by sponges at ecologically relevant quantities $[127,130]$ and can facilitate the growth of nearby primary producers such as corals and algae [131, 132]. Sponge-associated microbes are also involved in the cycling of other key limiting nutrients such as phosphorous. While sponges have been shown to release inorganic-phosphorous in the form of 
phosphate $[62,119,133,134]$, the discovery of abundant intracellular polyphosphate granules in the microbial symbionts of three phylogenetically distinct reef sponge species suggests the sponge microbiome may also mediate a pathway for phosphorous sequestration on coral reefs [135]. These microbial-generated storage granules can account for up to $40 \%$ of the total sponge phosporous content, and thus may substantially influence phosphorous availability in habitats with high sponge biomasses $[135,136]$. The sponge microbiome therefore influences both the quantity and speciation of inorganic nutrients made available to neighboring primary producers in coral reefs and other benthic ecosystems (Fig. 2).

\section{Chemical defense and predation}

The sponge microbiome also conveys defensive capacities to the host that strongly influence the interactions between sponges and other organisms within benthic communities (Fig. 2). Sponge holobionts produce a diverse array of secondary metabolites with antiviral, antimicrobial, cytotoxic, allelopathic, and antipredatory effects $[10,129,137,138]$, some of which have been attributed to the microbiome $[79,80,139]$. The production of biologically active feeding deterrent compounds is a common defensive strategy employed by sponges to avoid predation [140-142]. One of the earliest studies to link a sponge-derived secondary metabolite to the microbiome found that compounds isolated from the cyanobacterial symbionts of the sponge Lamellodysidea herbacea deterred fish feeding [143]. Subsequent studies have found increasing evidence that the microbiome is actively involved in the production of bioactive compounds with putative anti-predatory effects in a range of chemically defended sponge species $[10,79$, $144,145]$. Predation is a major process governing benthic community structure and can alter sponge community composition at sub-meter to habitat scales [146-148]. In habitats with high abundances of sponge predators, sponges without chemical defenses may be entirely excluded [148-150]. By influencing holobiont susceptibility to predation, the sponge microbiome thereby influences benthic community structure.

\section{Competition}

Spatial competition is another important biotic factor structuring benthic communities, and the sponge microbiome can mediate such interspecific interactions through a combination of metabolic and chemical defensive functions that enhance the competitive capacity of the holobiont (Fig. 2). For example, the abundant cyanobacterial symbionts of the coral-killing sponge Terpios hoshinota [151] play a key role in enabling the Terpios holobiont to aggressively overgrow a wide range of coral species [152, 153]. They not only provide cytotoxic secondary metabolites [154] but also photosynthates that enhance the physiological performance of the host $[153,155]$. Impairing the photosynthetic capacity of the symbionts through shading stops the growth of the sponge and prevents it overgrowing adjacent corals [153], demonstrating the importance of the symbionts in mediating these competitive interactions. Outbreaks of Terpios hoshinota have been implicated in causing widespread coral mortality [156, 157]. Consequently, this provides an example of how symbionts can dramatically influence holobiont competitiveness and thereby alter benthic community dynamics with catastrophic results.

These five examples highlight how the sponge microbiome can influence functioning at the holobiont, community, and ecosystem scale through the concept of nested ecosystems. Moreover, these microbiome-mediated functions are in turn shaped by environmental factors that also act on multiple scales [158] and feedback on the functioning of the holobiont by modifying sponge primary productivity, nutrient fluxes, and chemical defenses [134, 159-161]. Thus, future studies need to target the mechanisms behind host-symbiont interactions and link multiple scales if we are to unravel how the sponge microbiome may alter holobiont functioning under future environmental changes.

\section{Holobiont responses: stress, dysbiosis, and acclimatization Holobiont health}

The healthy holobiont is considered an ecosystem that is in a state of dynamic equilibrium. Like in any ecosystem, the strength and outcome (i.e., beneficial, neutral, or detrimental) of the interactions among the members of the holobiont may be affected by perturbations that challenge the healthy equilibrium (Fig. 3). Upon disturbance, alternative scenarios are possible. On the one hand, homeostasis can maintain healthy baseline conditions through mechanisms of resistance or resilience [162]. On the other hand, perturbations may disrupt the balance, leading to dysbiosis and, potentially, disease [163, 164]. Moreover, perturbations may act as a selective force (at the microbial, host, and/or holobiont level) so that the system reaches a new healthy state that allows it to better cope with environmental change (i.e., acclimatization). If the new features enhance holobiont fitness and can be transmitted to new generations, they may yield holobiont adaptation sensu lato [165]. The holobiont concept provides the framework to elucidate sponge responses to environmental change, the role of dysbiosis in disease, and the contribution of the microbiota to holobiont persistence. 


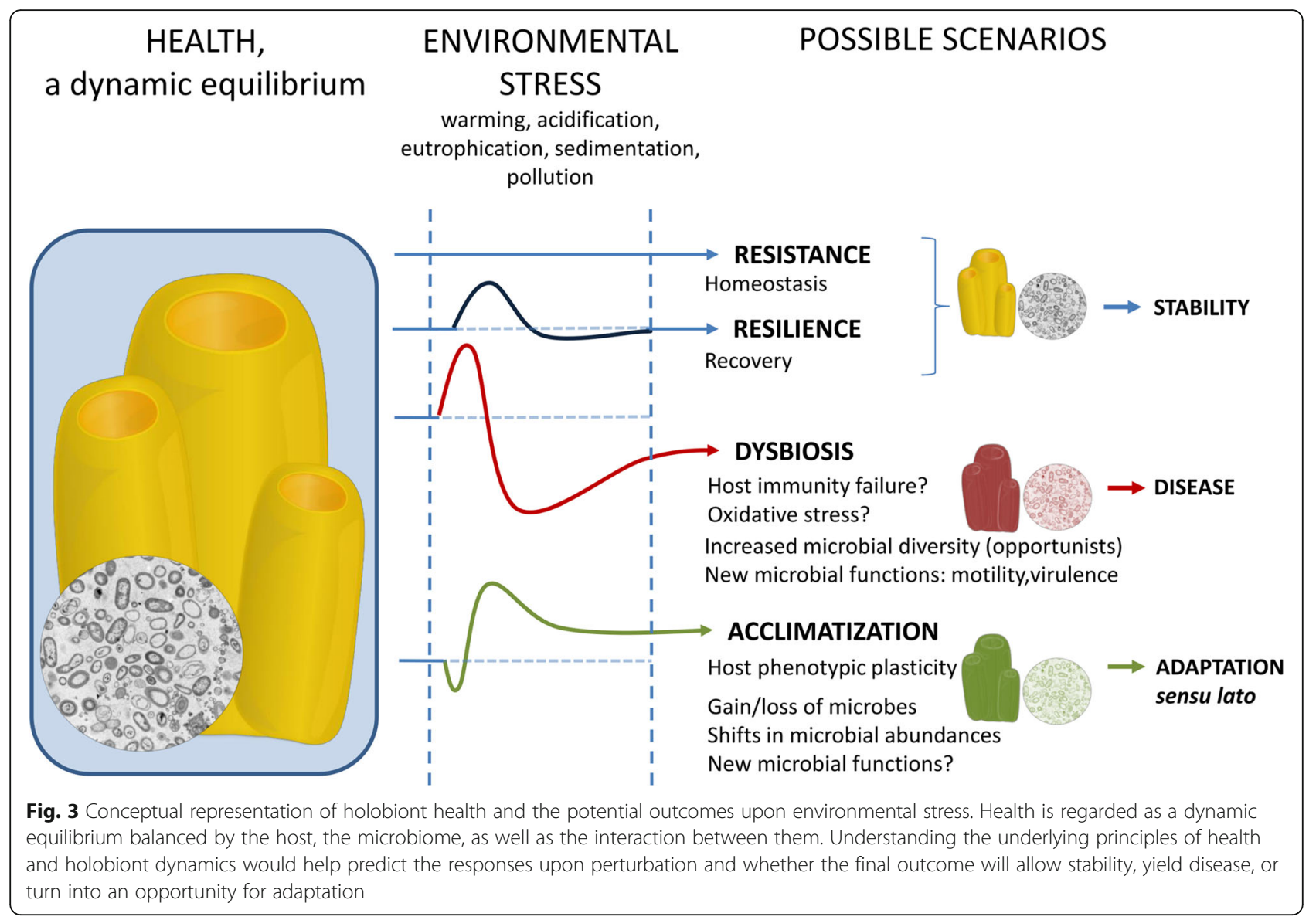

\section{Stress and dysbiosis}

Human activities are modifying the marine environment at a pace never before recorded [166]. Some of the major anthropogenic stressors threatening the oceans are climate change (ocean warming and acidification) and the deterioration of water quality (e.g., eutrophication, sedimentation, and pollution). But what are the consequences of these environmental stressors for sponge-associated microbial communities (Table 2)? Some studies report non-significant changes in the microbial community structure upon perturbations such as warming, increased sedimentation, or enriched nutrient concentrations, at least at sub-lethal stress levels [167-170]. The strength of the perturbations is therefore a major factor determining the ability of the holobiont to maintain a stable state. For example, the resilience of Xestospongia muta to bleaching (i.e., the ability to recover its cyanobacterial population) was only possible as long as stress was kept below a certain threshold [171]. Beyond these thresholds, significant shifts of the sponge-associated microbiota are commonly reported, mainly in already necrotic tissues as well as in apparently healthy tissues in contact with necrotic areas $[158,172]$.
Stress can induce dysbiosis: a disruption of the symbiotic community diversity. In sponges, it is often characterized by an increased alpha diversity [173] and/or a shift from sponge-enriched microbes (closely related to other sponge symbionts) to opportunists (microbes closely related to free-living organisms) [167]. Even in the absence of significant changes in alpha-diversity, stress-related increases of beta-diversity (dissimilarity between samples) have been observed in manipulative experiments [170, 174], as well as under natural perturbations [41]. This observation is consistent with the recently proposed "Anna Karenina principle," which suggests that intraspecific variability is higher in dysbiotic than in healthy individuals [175]. In terms of function, dysbiosis has been correlated with an enrichment of cell motility, chemotaxis, or virulence genes in stressed tissues compared to healthy controls $[158,176]$.

Stress may also compromise host physiology and immunity [177-179], entailing loss of control over the microbiome; thus, dysbiosis could be responsive rather than causal. To date, few studies have investigated the molecular response of the sponge host upon perturbation, and they have mainly focused on thermal stress in the sponge host using real-time quantitative PCR [158, 
Table 2 Response of sponge microbiome to environmental stressors

\begin{tabular}{|c|c|c|c|c|c|}
\hline \multirow[t]{2}{*}{ Sponge species } & \multicolumn{3}{|l|}{ Microbial response } & \multirow{2}{*}{$\begin{array}{l}\text { Host } \\
\text { response }\end{array}$} & \multirow[t]{2}{*}{ Ref. } \\
\hline & Method & Diversity & Function & & \\
\hline \multicolumn{6}{|l|}{ OCEAN WARMING } \\
\hline Geodia barreti & EMP pipeline & No & - & Ecophysiology & [168] \\
\hline Rhopaloeides odorabile & TRFLP; metagenomics & Yes & Yes & RT-qPCR & [158] \\
\hline R. odorabile & $\begin{array}{l}\text { pyrosequencing on } \\
\text { DNA and cDNA }\end{array}$ & Yes & - & - & [182] \\
\hline R. odorabile larva & DGGE & Yes & - & - & [231] \\
\hline R. odorabile & DGGE and cloning & Yes & - & - & [232] \\
\hline Ircinia fasciculata, I. oros & TRFLP & No & - & - & [233] \\
\hline I. fasciculata & PAM fluorometry & - & Yes & - & [194] \\
\hline lanthella basta & DGGE and cloning & Yes & - & - & [173] \\
\hline Xestospongia muta & $\begin{array}{l}\text { TRFLP, cloning and } \\
\text { RT-qPCR of amoA gene }\end{array}$ & Yes & Yes & - & [234] \\
\hline Halichondria bowerbanki & DGGE & Yes & - & - & [235] \\
\hline \multicolumn{6}{|l|}{ OCEAN ACIDIFICATION } \\
\hline $\begin{array}{l}\text { Dysidea avara, Agelas } \\
\text { oroides, Chondrosia reniformis }\end{array}$ & Pyrosequencing & spp-specific & - & Growth & [213] \\
\hline $\begin{array}{l}\text { Coelocarteria singaporensis, } \\
\text { Cinachyra sp }\end{array}$ & Pyrosequencing; PICRUST & Cyano & yes & - & {$[47]$} \\
\hline \multicolumn{6}{|l|}{$\begin{array}{l}\text { Ocean warming and } \\
\text { ocean acidification }\end{array}$} \\
\hline X. muta & $\begin{array}{l}\text { Pyrosequencing and } \\
\text { PICRUST; PAM fluorometry }\end{array}$ & Yes & yes & - & [174] \\
\hline $\begin{array}{l}\text { Carteriospongia foliascens; } R \text {. } \\
\text { odorabile; Stylissa flabelliformis; } \\
\text { Cymbastella coralliophila }\end{array}$ & PAM fluorometry & - & yes & Ecophysiology & [183] \\
\hline \multicolumn{6}{|c|}{ EUTROPHICATION, SEDIMENTATION, POLLUTION } \\
\hline $\begin{array}{l}\text { C. foliascens, C. coralliophila; Cliona } \\
\text { orientalis, Coscinoderma } \\
\text { matthewsi, S. flabelliformis }\end{array}$ & Illumina; PAM fluorometry & spp-specific & no & Ecophysiology & [170] \\
\hline Cymbastela stipitata & Pyrosequencing on DNA and cDNA & No & - & - & [169] \\
\hline Haliclona cymaeoformis & Pyrosequencing; metagenomics & Yes & yes & - & [176] \\
\hline 1. basta & DGGE & No & - & - & [173] \\
\hline R. odorabile & RFLP; FISH & Yes & - & - & [236] \\
\hline \multicolumn{6}{|l|}{ Ocean warming and eutrophication } \\
\hline R. odorabile & $\begin{array}{l}\text { DGGE and pyrosequencing; } \\
\text { DGGE of amoA gene }\end{array}$ & No & - & - & [167] \\
\hline
\end{tabular}

Responses were assessed in aquarium experiments, except for reference [47]. Molecular analyses were performed on 16S rRNA gene, unless stated otherwise. Fun. function. Ref references, Spp-specific species-specific response. EMP pipeline standardized protocol applied during the global Sponge Microbiome Project following Earth Microbiome Project guidelines. TRFLP terminal restriction fragment length polymorphism, RFLP restriction fragment length polymorphism, DGGE denaturing gradient gel electrophoresis. RT-qPCR real-time quantitative PCR. PICRUST function was inferred from taxonomic diversity by PICRUST tool [237]. PAM fluorometry pulse amplitude modulated diving fluorometer as measurement of photosynthetic capacity

171, 172, 180] or transcriptomics [181]. These studies showed that the $h s p 70$ gene as well as apoptosis-related, signaling, and oxidative stress-related genes are involved in sponge response to thermal stress. For example, host gene expression changes in Rhopaloeides odorabile were observed at sublethal temperatures $\left(31^{\circ} \mathrm{C}\right)$ [172], as well as at lethal temperatures $\left(32{ }^{\circ} \mathrm{C}\right)$ that coincided with necrosis [158]. The downregulation of oxidative stress- related and signaling genes, such as glutathione-Stransferase and calmodulin, in $R$. odorabile adults suggests fatal loss of function related to stress and was accompanied by dysbiosis [158, 182]. Additionally, physiological stress in sponges has been assessed in response to ocean warming and sedimentation by monitoring respiration, nutrient fluxes, or lipid content $[168,170,183]$. Responses were highly variable, species- 
specific, and dependent on the duration and strength of the treatment. Unlike in cnidarians [184-186], sponge immune ecology (i.e., patterns of immune gene expression along natural gradients and under environmental stress) remains largely unexplored and the link between differential gene expression levels and physiology is still missing.

\section{Diseases}

We are witnessing an unprecedented increase of disease and disease-like syndromes affecting a range of benthic organisms, including sponges, corals, and algae [187189], some of which are resulting in recurrent mass mortality events [190]. The underlying causes are mostly unknown, but disease outbreaks seem to respond to multiple factors, such as cumulative environmental pressures that trigger physiological stress and the proliferation of opportunistic, as well as pathogenic microbes [191-193]. As for humans [163], dysbiosis has been proposed as an additional explanation for the increased susceptibility of marine organisms to disease [164].

In sponges, disease outbreaks resulting in drastically decimated population sizes have been reported worldwide [189]. In the Mediterranean Sea, 80-95\% of Ircinia fasciculata and Sarcotragus spinosulum specimens died in the summers of 2008 and 2009 [194, 195]. In the Great Barrier Reef, a widespread distribution of a disease-like syndrome characterized by brown spot lesions and tissue necrosis has been observed in Ianthella basta, a common Indo-Pacific sponge species [196, 197]. Isolating and identifying causative agents has been unsuccessful so far $[198,199]$ (with the exception of pathogenic Pseudoalteromonas agarivorans strain NW4327 found in diseased Great Barrier Reef sponge Rhopaloeides odorabile [200, 201]). However, in many of these studies, diseased specimens showed divergent microbial profiles compared with the healthy individuals [202206]. For example, diseased individuals of the deep-sea sponge Geodia barretti showed higher relative abundances of Bacteroidetes, Firmicutes, and Deltaproteobacteria than healthy ones [204], whereas in the Mediterranean sponge Ircinia fasciculata [202], the early-diseased (i.e., near to necrotic) tissue showed enrichment of Gammaproteobacteria and Acidobacteria groups but depletion of Deltaproteobacteria. However, in both cases, the sponge-associated microbiota shifted from a specific- to a generalist-dominated community in the unhealthy individuals. These findings indicate that, similar to corals $[207,208]$, sponge diseases appear to start with an imbalance of the holobiont which is then followed by opportunistic or polymicrobial infections.

\section{Acclimatization and adaptation: when change is good}

Alterations in the symbiotic microbial community upon environmental stress can potentially lead to holobiont acclimatization and even adaptation [165]. Although the host can also respond to perturbations through phenotypic plasticity [209], microbial-mediated acclimatization has received special attention since microorganisms have shorter generation times and accordingly respond much more rapidly and versatilely than the host itself [210]. The microbial genetic information can either change through the introduction of new microorganisms from the environment or by genetic alteration of the associated microbiome through mutation and/or HGT leading to the acquisition of novel functions without shifts in taxonomic composition [211, 212]. Hence, novel acquired traits and functions in the microbiome could significantly affect the holobiont phenotype leading to acclimatization. If those new traits are vertically transmitted, they will facilitate microbiome-mediated transgenerational acclimatization upon which selection could act potentially leading to holobiont adaptation [165].

A recent study suggests that changes in the microbial community contribute to the ability of the sponge holobiont to cope with environmental change [213]. The effect of ocean acidification was assessed in three ubiquitous Mediterranean sponges (Dysidea avara, Agelas oroides, and Chondrosia reniformis) [213]. While the overall microbial abundance, richness, and diversity were not affected, species-specific differences in the acquisition of new microbes were observed: high acquisition in D. avara, moderate in A. oroides, and null in C. reniformis. This variation in microbial acquisition was inversely correlated with growth rate as growth was not affected in D. avara, reduced in A. oroides and severely reduced in $C$. reniformis. These results, together with evidence from coral holobionts [210, 214], suggest that symbiotic microbes influence the holobiont's capacity to acclimate to changing environmental conditions.

\section{Sponges under future-ocean scenarios}

It has been hypothesized that sponges may be "winners" under projected global change scenarios compared with other benthic invertebrates like corals [215]. Increased sponge abundances have been observed in some habitats [215], but they are often linked to proliferation of only a few or single species and thus accompanied by an overall loss of species diversity [216-218]. Other studies have documented localized losses in both sponge diversity and abundances [219] and for many more habitats, particularly in deep-sea sponge grounds, we lack baseline data $[26,218]$. Sponge mass mortality events in response to environmental perturbations [191, 220] combined with the results from experimental studies (Table 2) indicate that sponge diversity and function will change in the future, with unknown cascading ecosystem effects. Moreover, baseline data and diagnostic tools to detect these changes are lacking [221]. Microbial monitoring 
was proposed as a diagnostic tool since microbes potentially serve as early warning indicators for stress at both the holobiont and the ecosystem level [164, 222]. In combination with traditional ecological monitoring programs, microbial monitoring would allow us (i) to acquire missing baseline data, (ii) to predict approaching tipping points, and (iii) to identify long-term trends that may inform management [223, 224]. Ultimately, this would enable intervention before the key ecosystem functions provided by sponges are lost.

\section{Box 3 Future directions in sponge holobiont research}

1. Adopt a true holobiont approach. Define and elucidate the functional roles of the missing holobiont members. Microbial groups other than bacterial and archaea, such as viruses or microbial eukaryotes, remain understudied. Advance the understanding of the drivers of microbial assembly and microbe-microbe interactions. Define the role of the host as an ecosystem engineer and determine the mechanisms underpinning host-microbe interactions.

2. Integrate the concept of nested ecosystems into holobiont research. Validate and quantify the influence of the sponge microbiome at the holobiont, community, and ecosystem scale. Determine how environmental factors can alter microbiomemediated processes and link mechanisms at multiple scales. It will also be important to consider that different sponge holobionts fulfill different functions and that functioning varies across environments. Research has largely focused on shallow-water ecosystems while the deep-sea remains understudied.

\section{Determine the drivers and processes governing holobiont}

health and stability. Unravel the relationships between diversity, function, and holobiont stability and establish the mechanisms behind resistance and resilience. Determine the role of functional redundancy in contributing to holobiont stability. Disentangle the linkages between stress, dysbiosis, and disease in sponge holobionts and elucidate whether dysbiosis is a cause or consequence of disease. Evaluate the role of microbes in mediating holobiont acclimatization and adaptation to environmental change.

4. Monitoring, management, and solutions. Develop long-term monitoring strategies to collect missing baseline data and identify long-term trends. Assess the vulnerability of sponge holobionts to global change and other anthropogenic stressors, and develop management solutions to ensure the maintenance of sponge holobiont functions at the ecosystem level. This will entail multidisciplinary approaches that combine experimental, field, and genomic/transcriptomic data.

\section{Conclusion}

In this review, we have examined the sponge holobiont from the micro- to the global scale. Advances in sponge microbiology have revealed the principles of diversity and core functions, but linking microbial diversity with function would provide additional insights into sponge holobiont health. Sponges illustrate the concept of nested ecosystems, providing a new framework for understanding holobionts in the marine environment. Future research should attempt to connect these multiple scales in order to understand which microbial features contribute to sponge holobiont functioning and to what extent they impact the surrounding ecosystem. The response of the holobiont to environmental stress requires the evaluation of both host and microbiota in a true holobiont approach. Defining the relationship between stress, dysbiosis, and disease requires moving beyond patterns to mechanisms that can establish cause and consequence. Only then can we disentangle the underlying principles of health in sponge holobionts, improve predictions of the fate of sponges in future oceanscenarios, and develop effective management strategies accordingly.

\section{Abbreviations \\ CRISPR: Clustered regularly interspaced short palindromic repeats; DGGE: Denaturing gradient gel electrophoresis; DIN: Dissolved inorganic nitrogen; DOM: Dissolved organic matter; ELP: Eukaryotic-like proteins; EMP: Earth microbiome project; HGT: Horizontal gene transfer; LPS: Lipopolysaccharide; POM: Particulate organic matter; PRR: Pattern recognition receptor; RFLP: Restriction fragment length polymorphism; RT- qPCR: Real-time quantitative polymerase chain reaction; SRCR: Scavenger receptor cysteine-rich; TRFLP: Terminal restriction fragment length polymorphism}

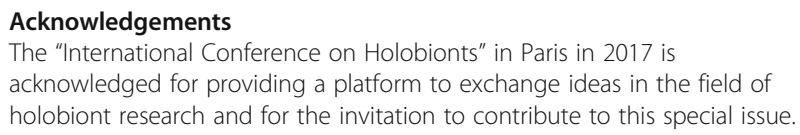

LP was awarded a postdoctoral fellowship from the Alexander von Humboldt Foundation, which was sponsored by The Future Ocean Cluster. BMS and UH were supported by the European Union's Horizon 2020 research and innovation program under grant agreement 679849 ("SponGES"). AF was supported by the strategic research initiative "Ocean Health" of The Future Ocean Cluster. UH received financial support from the DFG (CRC1182-TPB1).

\section{Availability of data and materials}

The data used to create Fig. 1 was published by Thomas et al. [23] as Supplementary Data 3 (representative sequences and taxonomy of OTUs) taking into account only OTUs occurring in sponge samples (see Supplementary Data 4 and Supplementary Data 2 in [23]).

\section{Authors' contributions}

LP and LR contributed equally to this work. All authors listed have made substantial, direct, and intellectual contribution to the work, and approved it for publication. All authors read and approved the final manuscript.

Ethics approval and consent to participate Not applicable. 


\section{Consent for publication}

Not applicable.

\section{Competing interests}

The authors declare that they have no competing interests.

\section{Publisher's Note}

Springer Nature remains neutral with regard to jurisdictional claims in published maps and institutional affiliations.

\section{Author details}

${ }^{1}$ RD3 Marine Microbiology, GEOMAR Helmholtz Centre for Ocean Research, Kiel, Germany. ${ }^{2}$ Christian-Albrechts-University of Kiel (CAU), Kiel, Germany.

\section{Received: 15 November 2017 Accepted: 20 February 2018 Published online: 09 March 2018}

\section{References}

1. Worden AZ, Follows MJ, Giovannoni SJ, Wilken S, Zimmerman AE, Keeling PJ. Rethinking the marine carbon cycle: factoring in the multifarious lifestyles of microbes. Science. 2015;347:1257594.

2. Bork P, Bowler C, de Vargas C, Gorsky G, Karsenti E, Wincker P. Tara oceans studies plankton at planetary scale. Science. 2015;348:873-5.

3. Apprill A. Marine animal microbiomes: toward understanding hostmicrobiome interactions in a changing ocean. Front Mar Sci. 2017;4:222.

4. Egan S, Harder T, Burke C, Steinberg P, Kjelleberg S, Thomas T. The seaweed holobiont: understanding seaweed-bacteria interactions. FEMS Microbiol Rev. 2013;37:462-76.

5. McFall-Ngai M, Hadfield MG, Bosch TCG, Carey HV, Domazet-Lošo T, Douglas AE, et al. Animals in a bacterial world, a new imperative for the life sciences. Proc Natl Acad Sci U S A. 2013:110:3229-36.

6. Bosch TCG, McFall-Ngai MJ. Metaorganisms as the new frontier. Zoology. 2011:114:185-90.

7. Bordenstein SR, Theis KR. Host biology in light of the microbiome: ten principles of holobionts and hologenomes. PLoS Biol. 2015;13:e1002226.

8. Rohwer F, Seguritan V, Azam F, Knowlton N. Diversity and distribution of coral-associated bacteria. Mar Ecol Prog Ser. 2002;243:1-10.

9. Nicholson J, Holmes E, Kinross J, Burcelin R, Gibson G, Jia W, et al. Host-gut microbiota metabolic interactions. Science. 2012;336:1262-7.

10. Flórez LV, Biedermann PHW, Engl T, Kaltenpoth M, Florez LV, Biedermann PHW, et al. Defensive symbioses of animals with prokaryotic and eukaryotic microorganisms. Nat Prod Rep. 2015;32:904-36.

11. Eberl G. A new vision of immunity: homeostasis of the superorganism. Mucosal Immunol. 2010;3:450-60.

12. Koropatnick TA, Engle JT, Apicella MA, Stabb EV, Goldman WE, McFall-Ngai MJ. Microbial factor-mediated development in a host-bacterial mutualism. Science. 2004;306:1186-8

13. Qin J, Li R, Raes J, Arumugam M, Burgdorf K, Manichanh C, et al. A human gut microbial gene catalogue established by metagenomic sequencing. Nature. 2010:464:59-65.

14. Tanca A, Abbondio M, Palomba A, Fraumene C, Manghina V, Cucca F, et al. Potential and active functions in the gut microbiota of a healthy human cohort. Microbiome. 2017:5:79.

15. Costello EK, Stagaman K, Dethlefsen L, Bohannan BJM, Relman DA. The application of ecological theory toward an understanding of the human microbiome. Science. 2012;336:1255-62

16. Fierer N, Ferrenberg S, Flores GE, González A, Kueneman J, Legg T, et al. From animalcules to an ecosystem: application of ecological concepts to the human microbiome. Annu Rev Ecol Evol Syst. 2012:43:137-55.

17. Sommer F, Anderson JM, Bharti R, Raes J, Rosenstiel P. The resilience of the intestinal microbiota influences health and disease. Nat. Rev. Microbiol. 2017;15(10):630-8

18. Adair KL, Douglas AE. Making a microbiome: the many determinants of host-associated microbial community composition. Curr Opin Microbiol. 2017;35:23-9.

19. Foster KR, Schluter J, Coyte KZ, Rakoff-Nahoum S. The evolution of the host microbiome as an ecosystem on a leash. Nature. 2017:548:43-51.

20. Koskella B, Hall $\amalg$, Metcalf CJE. The microbiome beyond the horizon of ecological and evolutionary theory. Nat Ecol Evol. 2017;1(11):1606.

21. Muscatine L, Porter J. Reef corals: mutualistic symbioses adapted to nutrient poor environments. Bioscience. 1977;27:454-60.
22. Wild C, Hoegh-Guldberg O, Naumann MS, Florencia Colombo-Pallotta M, Ateweberhan M, Fitt WK, et al. Climate change impedes scleractinian corals as primary reef ecosystem engineers. Mar Freshw Res. 2011;62:205-15.

23. Thomas T, Moitinho-Silva L, Lurgi M, Björk JR, Easson C, Astudillo-García C, et al. Diversity, structure and convergent evolution of the global sponge microbiome. Nat Commun. 2016;7:11870.

24. Moitinho-Silva L, Nielsen S, Amir A, Gonzalez A, Ackermann GL, Cerrano C, et al. The sponge microbiome project. Giga Sci. 2017;6:10.

25. Van Soest RWM, Boury-Esnault N, Vacelet J, Dohrmann M, Erpenbeck D, De Voogd NJ, et al. Global diversity of sponges (Porifera). PLoS One. 2012;7:e35105.26.

26. Maldonado M, Aguilar R, Bannister R, Bell J, Conway K, Dayton P, et al. Sponge grounds as key marine habitats: a synthetic review of types, structure, functional roles and conservation concerns. In: Rossi S, Bramanti L, Gori A, Orejas Saco del Valle C (eds) Springer, Cham. Marine Animal Forests. 2015;1-39.

27. Bell JJ. The functional roles of marine sponges. Estuar Coast Shelf Sci. 2008; 79:341-53.

28. Gili JM, Coma R. Benthic suspension feeders: their paramount role in littoral marine food webs. Trends Ecol Evol. 1998;13:316-21.

29. de Goeij JM, van Oevelen D, Vermeij MJA, Osinga R, Middelburg JJ, de Goeij AFPM, et al. Surviving in a marine desert: the sponge loop retains resources within coral reefs. Science. 2013;342:108-10.

30. Kahn AS, Yahel G, Chu JWF, Tunnicliffe V, Leys SP. Benthic grazing and carbon sequestration by deep-water glass sponge reefs. Limnol Oceanogr. 2015;60:78-88.

31. Thomas T, Rusch D, DeMaere MZ, Yung PY, Lewis M, Halpern A, et al. Functional genomic signatures of sponge bacteria reveal unique and shared features of symbiosis. ISME J. 2010;4:1557-67.

32. Kamke J, Sczyrba A, Ivanova N, Schwientek P, Rinke C, Mavromatis K, et al. Single-cell genomics reveals complex carbohydrate degradation patterns in poribacterial symbionts of marine sponges. ISME J. 2013;7:2287-300.

33. Slaby BM, Hackl T, Horn H, Bayer K, Hentschel U. Metagenomic binning of a marine sponge microbiome reveals unity in defense but metabolic specialization. ISME J. 2017:17(11):2465-78

34. Jahn MT, Markert SM, Ryu T, Ravasi T, Stigloher C, Hentschel U, et al Shedding light on cell compartmentation in the candidate phylum Poribacteria by high resolution visualisation and transcriptional profiling. Sci Rep. 2016:6:35860.

35. Moitinho-Silva L, Díez-Vives C, Batani G, Esteves Al, Jahn MT, Thomas T. Integrated metabolism in sponge-microbe symbiosis revealed by genomecentered metatranscriptomics. ISME J. 2017;11:1651-66.

36. Pita $\mathrm{L}$, Fraune $\mathrm{S}$, Hentschel $U$. Emerging sponge models of animal-microbe symbioses. Front Microbiol. 2016;7:2102

37. Hamady M, Knight R. Microbial community profiling for human microbiome projects: tools, techniques, and challenges. Genome Res. 2009;19:1141-52.

38. Erwin PM, López-Legentil S, González-Pech R, Turon X. A specific mix of generalists: bacterial symbionts in Mediterranean Ircinia spp. FEMS Microbiol Ecol. 2012;79:619-37.

39. Hester ER, Barott KL, Nulton J, Vermeij MJA, Rohwer FL. Stable and sporadic symbiotic communities of coral and algal holobionts. ISME J. 2015;10:1157-69.

40. Pita L, Turon X, López-Legentil S, Erwin PM. Host rules: spatial stability of bacterial communities associated with marine sponges (Ircinia spp.) in the western Mediterranean Sea. FEMS Microbiol Ecol. 2013;86:268-76.

41. Erwin PM, Pita L, López-Legentil S, Turon X. Stability of sponge-associated bacteria over large seasonal shifts in temperature and irradiance. Appl Environ Microbiol. 2012;78:7358-68.

42. Erwin PM, Coma R, López-Sendino P, Serrano E, Ribes M. Stable symbionts across the HMA-LMA dichotomy: low seasonal and inter-annual variation in sponge-associated bacteria from taxonomically diverse hosts. FEMS Microbiol. 2015;91:fiv115.

43. Steinert G, Taylor MW, Deines P, Simister RL, de Voogd NJ, Hoggard M, et al In four shallow and mesophotic tropical reef sponges from Guam the microbial community largely depends on host identity. PeerJ. 2016;4:e1936.

44. Cárdenas CA, Bell JJ, Davy SK, Hoggard M, Taylor MW. Influence of environmental variation on symbiotic bacterial communities of two temperate sponges. FEMS Microbiol Ecol. 2014:88(3):516-27.

45. Steinert G, Rohde S, Schupp PJ, Steinert G, Rohde S, Janussen D, et al. Hostspecific assembly of sponge- associated prokaryotes at high taxonomic ranks. Sci Rep. 2017;7:2542. 
46. Astudillo-García C, Bell JJ, Webster NS, Glasl B, Jompa J, Montoya JM, et al Evaluating the core microbiota in complex communities: a systematic investigation. Environ Microbiol. 2017;19:1450-62.

47. Morrow KM, Bourne DG, Humphrey C, Botte ES, Laffy P, Zaneveld J, et al, Natural volcanic CO2 seeps reveal future trajectories for host-microbial associations in corals and sponges. ISME J. 2015:9:894-908.

48. Morrow KM, Fiore CL, Lesser MP. Environmental drivers of microbial community shifts in the giant barrel sponge, Xestospongia muta, over a shallow to mesophotic depth gradient. Environ Microbiol. 2016;18:2025-38.

49. Weigel BL, Erwin PM. Effects of reciprocal transplantation on the microbiome and putative nitrogen cycling functions of the intertidal sponge, Hymeniacidon heliophila. Sci Rep. 2017;7:43247.

50. Deines $P$, Bosch TCG. Transitioning from microbiome composition to microbial community interactions: the potential of the metaorganism Hydra as an experimental model. Front Microbiol. 2016;7:1610.

51. McNally L, Brown SP. Ecology of stable gut communities. Nat Microbiol. 2016;1:15016.

52. Coyte KZ, Schluter J, Foster KR. The ecology of the microbiome: networks, competition, and stability. Science. 2015;350:663-6.

53. Fan L, Reynolds D, Liu M, Stark M, Kjelleberg S, Webster NS, et al. Functional equivalence and evolutionary convergence in complex communities of microbial sponge symbionts. Proc Natl Acad Sci U S A. 2012;109:e1878-87.

54. Liu M, Fan L, Zhong L, Kjelleberg S, Thomas T. Metaproteogenomic analysis of a community of sponge symbionts. ISME J. 2012;6:1515-25.

55. Radax R, Rattei T, Lanzen A, Bayer C, Rapp HT, Urich T, et al. Metatranscriptomics of the marine sponge Geodia barretti: tackling phylogeny and function of its microbial community. Environ Microbiol. 2012:14:1308-24.

56. Gauthier M-EA, Watson JR, Degnan SM. Draft genomes shed light on the dual bacterial symbiosis that dominates the microbiome of the coral reef sponge Amphimedon queenslandica. Front Mar Sci. 2016;3:196.

57. Siegl A, Kamke J, Hochmuth T, Piel J, Richter M, Liang C, et al. Single-cell genomics reveals the lifestyle of Poribacteria, a candidate phylum symbiotically associated with marine sponges. ISME J. 2011;5:61-70.

58. Kamke J, Rinke C, Schwientek P, Mavromatis K, Ivanova N, Sczyrba A, et al The candidate phylum Poribacteria by single-cell genomics: new insights into phylogeny, cell-compartmentation, eukaryote-like repeat proteins, and other genomic features. PLoS One. 2014;9:e87353.

59. Liu F, Li J, Feng G, Li Z. New genomic insights into "Entotheonella" symbionts in Theonella swinhoei: Mixotrophy, anaerobic adaptation, resilience, and interaction. Front Microbiol. 2016;7:1333.

60. Hentschel U, Piel J, Degnan SM, Taylor MW. Genomic insights into the marine sponge microbiome. Nat Rev Microbiol. 2012;10:641-54

61. Horn H, Slaby B, Jahn M, Bayer K, Moitinho-silva L, Förster F, et al. An enrichment of CRISPR and other defense-related features in marine spongeassociated microbial metagenomes. Front Microbiol. 2016;7:1751.

62. Ribes M, Jimenez E, Yahel G, Lopez-Sendino P, Diez B, Massana R, et al. Functional convergence of microbes associated with temperate marine sponges. Environ Microbiol. 2012;14:1224-39.

63. Zan J, Cicirelli EM, Mohamed NM, Sibhatu H, Kroll S, Choi O, et al. A complex LuxR-Luxl type quorum sensing network in a roseobacterial marine sponge symbiont activates flagellar motility and inhibits biofilm formation. Mol Microbiol. 2012;85:916-33.

64. Bayer K, Moitinho-Silva L, Brümmer F, Cannistraci CV, Ravasi T, Hentschel U. GeoChip-based insights into the microbial functional gene repertoire of marine sponges (HMA, LMA) and seawater. FEMS Microbiol Ecol. 2014;90:832-43.

65. Moitinho-Silva L, Seridi L, Ryu T, Voolstra CR, Ravasi T, Hentschel U. Revealing microbial functional activities in the Red Sea sponge Stylissa carteri by metatranscriptomics. Environ Microbiol. 2014;16:3683-98.

66. Li Z, Wang Y, Li J, Liu F, He L, He Y, et al. Metagenomic analysis of genes encoding nutrient cycling pathways in the microbiota of deep-sea and shallow-water sponges. Mar Biotechnol. 2016;18:659-71.

67. Radax R, Hoffmann F, Rapp HT, Leininger S, Schleper C. Ammonia-oxidizing archaea as main drivers of nitrification in cold-water sponges. Environ Microbiol. 2012;14:909-23.

68. Li Z-Y, Wang Y-Z, He L-M, Zheng H-J. Metabolic profiles of prokaryotic and eukaryotic communities in deep-sea sponge Neamphius huxleyi indicated by metagenomics. Sci Rep. 2015;4:3895.

69. Hoffmann F, Radax R, Woebken D, Holtappels M, Lavik G, Rapp HT, et al. Complex nitrogen cycling in the sponge Geodia barretti. Environ Microbiol. 2009;11:2228-43.
70. Mohamed NM, Colman AS, Tal Y, Hill RT. Diversity and expression of nitrogen fixation genes in bacterial symbionts of marine sponges. Environ Microbiol. 2008;10:2910-21.

71. Zhang F, Vicente J, Hill RT. Temporal changes in the diazotrophic bacterial communities associated with Caribbean sponges Ircinia stroblina and Mycale laxissima Front. Microbiol. 2014:5:561.

72. Fiore $\mathrm{CL}$, Labrie $\mathrm{M}$, Jarett JK, Lesser MP, Jarettt JK, Lesser MP. Transcriptional activity of the giant barrel sponge, Xestospongia muta holobiont : molecular evidence for metabolic interchange. Front Microbiol. 2015;6:364.

73. Ribes M, Dziallas C, Coma R, Riemann L. Microbial diversity and putative diazotrophy in high- and low-microbial-abundance Mediterranean sponges. Appl Environ Microbiol. 2015:81:5683-93.

74. Hoffmann F, Larsen O, Thiel V, Rapp HT, Pape T, Michaelis W, et al. An anaerobic world in sponges. Geomicrobiol J. 2005;22:1-10.

75. Schläppy ML, Schöttner SI, Lavik G, Kuypers MMM, de Beer D, Hoffmann F. Evidence of nitrification and denitrification in high and low microbial abundance sponges. Mar Biol. 2010;157:593-602.

76. Lavy A, Keren R, Yahel G, Ilan M. Intermittent hypoxia and prolonged suboxia measured in situ in a marine sponge. Front Mar Sci. 2016;7:263.

77. Webster NS, Thomas T. The sponge hologenome. MBio. 2016;7:e00135-16.

78. Astudillo-García C, Slaby BM, Waite DW, Bayer K, Hentschel U, Taylor MW. Phylogeny and genomics of SAUL, an enigmatic bacterial lineage frequently associated with marine sponges. Environ Microbiol. 2018;20:561-76.

79. Lackner G, Peters EE, Helfrich EJN, Piel J, Edzard E, Helfrich EJN, et al. Insights into the lifestyle of uncultured bacterial natural product factories associated with marine sponges. Proc Natl Acad Sci U S A. 2017;114:E347-56.

80. Wilson MC, Mori T, Ruckert C, Uria AR, Helf MJ, Takada K, et al. An environmental bacterial taxon with a large and distinct metabolic repertoire. Nature. 2014;506:58-62.

81. Nguyen MTHD, Liu M, Thomas T. Ankyrin-repeat proteins from sponge symbionts modulate amoebal phagocytosis. Mol Ecol. 2014;23:1635-45.

82. Díez-Vives C, Moitinho-Silva L, Nielsen S, Reynolds D, Thomas T. Expression of eukaryotic-like protein in the microbiome of sponges. Mol Ecol. 2017;26:1432-51.

83. Burgsdorf I, Slaby BM, Handley KM, Haber M, Blom J, Marshall CW, et al. Lifestyle evolution in cyanobacterial symbionts of sponges. MBio. 2015;6:e00391-15.

84. Wehrl M, Steinert M, Hentschel U. Bacterial uptake by the marine sponge Aplysina aerophoba. Microb Ecol. 2007:53:355-65.

85. Gao Z-M, Wang Y, Tian R-M, Wong YH, Batang ZB, Al-Suwailem AM, et al. Symbiotic adaptation drives genome streamlining of the cyanobacterial sponge symbiont "Candidatus Synechococcus spongiarum.". MBio. 2014;5:e00079-14.

86. Wilkinson CR, Garrone R, Vacelet J. Marine sponges discriminate between food bacteria and bacterial symbionts: electron microscope radioautography and in situ evidence. Proc R Soc L B. 1979;205:519-28.

87. Chu H, Mazmanian SK. Innate immune recognition of the microbiota promotes host-microbial symbiosis. Nat Immunol. 2013;14:668-75.

88. Degnan SM. The surprisingly complex immune gene repertoire of a simple sponge, exemplified by the NLR genes: a capacity for specificity? Dev Comp Immunol. 2015;48:269-74.

89. Ryu T, Seridi L, Moitinho-Silva L, Oates M, Liew YJ, Mavromatis C, et al. Hologenome analysis of two marine sponges with different microbiomes. BMC Genomics. 2016;17:158.

90. Steindler L, Schuster S, Ilan M, Avni A, Cerrano C, Beer S. Differential gene expression in a marine sponge in relation to its symbiotic state. Mar Biotechnol. 2007;9:543-9.

91. Yuen B. Deciphering the genomic toolkit underlying animal-bacteria interactions-insights through the demosponge Amphimedon queenslandica. $\mathrm{PhD}$ thesis, School of Biological Science, The University of Queensland; 2016. https://doi.org/10.14264/uql.2017.39.

92. Wiens M, Korzhev M, Krasko A, Thakur NL, Perović-Ottstadt S, Breter HJ, et al, Innate immune defense of the sponge Suberites domuncula against bacteria involves a MyD88-dependent signaling pathway: induction of a perforin-like molecule. J Biol Chem. 2005;280:27949-59.

93. Schmitt S, Tsai P, Bell J, Fromont J, Ilan M, Lindquist N, et al. Assessing the complex sponge microbiota: core, variable and species-specific bacterial communities in marine sponges. ISME J. 2012;6:564-76.

94. Schmitt S, Angermeier H, Schiller R, Lindquist N, Hentschel U. Molecular microbial diversity survey of sponge reproductive stages and mechanistic insights into vertical transmission of microbial symbionts. Appl Environ Microbiol. 2008;74:7694-708. 
95. Webster NS, Taylor MW, Behnam F, Lücker S, Rattei T, Whalan S, et al. Deep sequencing reveals exceptional diversity and modes of transmission for bacterial sponge symbionts. Environ Microbiol. 2010;12:2070-82.

96. Usher KM, Kuo J, Fromont J, Sutton DC. Vertical transmission of cyanobacterial symbionts in the marine sponge Chondrilla australiensis (Demospongiae). Hydrobiologia. 2001;461:15-23.

97. Oren M, Steindler L, llan M. Transmission, plasticity and the molecular identification of cyanobacterial symbionts in the Red Sea sponge Diacarnus erythraenus. Mar Biol. 2005;148:35-41.

98. Fieth RA, Gauthier M-EA, Bayes J, Green KM, Degnan SM. Ontogenetic changes in the bacterial symbiont community of the tropical demosponge Amphimedon queenslandica: metamorphosis is a new beginning. Front Mar Sci. 2016:3:228.

99. Dubilier N, Bergin C, Lott C. Symbiotic diversity in marine animals: the art of harnessing chemosynthesis. Nat Rev Microbiol. 2008;6:725-40.

100. Freeman CJ, Thacker RW, Baker DM, Fogel ML. Quality or quantity: is nutrient transfer driven more by symbiont identity and productivity than by symbiont abundance? ISME J. 2013;7:1116-25.

101. Fiore CL, Baker DM, Lesser MP. Nitrogen biogeochemistry in the Caribbean sponge, Xestospongia muta: a source or sink of dissolved inorganic nitrogen? PLoS One. 2013;8:e72961.

102. Freeman CJ, Thacker RW. Complex interactions between marine sponges and their symbiotic microbial communities. Limnol Oceanogr. 2011;56:1577-86.

103. Wilkinson CR. Productivity and abundance of large sponge populations on Flinders reef flats, Coral Sea. Coral Reefs. 1987:5:183-8.

104. Wilkinson CR. Net primary productivity in coral reef sponges. Science. 1983; 219:410-2.

105. Erwin PM, Thacker RWR. Phototrophic nutrition and symbiont diversity of two Caribbean sponge-cyanobacteria symbioses. Mar Ecol Prog Ser. 2008;362:139-47.

106. Arillo A, Bavestrello G, Burlando B, Sarà M. Metabolic integration between symbiotic cyanobacteria and sponges: a possible mechanism. Mar Biol. 1993;117:159-62.

107. Thacker RW. Impacts of shading on sponge-cyanobacteria symbioses : a comparison between host-specific and generalist associations. Integr Comp Biol. 2005;45:369-76

108. Cardini U, Bednarz V, van Hoytema N, Rovere A, Naumann M, Al-Rshaidat M, et al. Budget of primary production and dinitrogen fixation in a highly seasonal Red Sea coral reef. Ecosystems. 2016;19:771-785.

109. Vacelet J, Fiala-Médioni A, Fisher CR, Boury-Esnault N. Symbiosis between methane-oxidizing bacteria and a deep-sea carnivorous cladorhizid sponge. Mar Ecol Prog Ser. 1996;145:77-85.

110. van Duyl FC, Hegeman J, Hoogstraten A, Maier C. Dissolved carbon fixation by sponge-microbe consortia of deep water coral mounds in the northeastern Atlantic Ocean. Mar Ecol Prog Ser. 2008;358:137-50.

111. Hestetun JT, Dahle H, Jørgensen SL, Olsen BR, Rapp HT. The microbiome and occurrence of methanotrophy in carnivorous sponges. Front Microbiol. 2016:7:1781.

112. Arellano SM, Lee OO, Lafi FF, Yang J, Wang Y, Young CM, et al. Deep sequencing of Myxilla (Ectyomyxilla) methanophila, an epibiotic sponge on cold-seep tubeworms, reveals methylotrophic, thiotrophic, and putative hydrocarbon-degrading microbialassociations. Microb Ecol. 2013;65:450-61.

113. Nishijima M, Lindsay DJ, Hata J, Nakamura A, Kasai H, Ise Y, et al. Association of thioautotrophic bacteria with deep-sea sponges. Mar Biotechnol. 2010;12:253-60.

114. Rix L, de Goeij JM, Mueller CE, Struck U, Middelburg JJ, van Duyl FC, et al. Coral mucus fuels the sponge loop in warm- and cold-water coral reef ecosystems. Sci Rep. 2016;6:18715.

115. Rix L, de Goeij JM, van Oevelen D, Struck U, Al-horani FA, Wild C, et al. Differential recycling of coral and algal dissolved organic matter via the sponge loop. Funct Ecol. 2016;31:778-89.

116. Yahel G, Sharp JH, Marie D, Hase C, Genin A. In situ feeding and element removal in the symbiont-bearing sponge Theonella swinhoei: bulk DOC is the major source for carbon. Limnol Oceanogr. 2003;48:141-9.

117. de Goeij JM, van den Berg H, van Oostveen MM, Epping EHG, Van Duyl FC. Major bulk dissolved organic carbon (DOC) removal by encrusting coral reef cavity sponges. Mar Ecol Prog Ser. 2008;357:139-51.

118. Mueller B, de Goeij JM, Vermeij MJA, Mulders Y, van der Ent E, Ribes M, et al. Natural diet of coral-excavating sponges consists mainly of dissolved organic carbon (DOC). PLoS One. 2014;9(2):e90152

119. Morganti T, Coma R, Yahel G, Ribes M. Trophic niche separation that facilitates co-existence of high and low microbial abundance sponges is revealed by in situ study of carbon and nitrogen fluxes. Limnol. Oceanography. 2017;62(5):1963-83.
120. McMurray SE, Johnson ZI, Hunt DE, Pawlik JR, Finelli CM. Selective feeding by the giant barrel sponge enhances foraging efficiency. Limnol. Oceanography. 2016;61(4):1271-86.

121. Leys SP, Kahn A, Fang J, Kutti T, Bannister R. Phagocytosis of microbial symbionts balances the carbon and nitrogen budget for the deep-water boreal sponge Geodia barretti. Limnol Oceanogr. 2018;63:187-202.

122. Hoer DR, Gibson PJ, Tommerdahl JP, Lindquist NL, Martens CS. Consumption of dissolved organic carbon by Caribbean reef sponges. Limnol Oceanogr. 2018;63:337-51.

123. Alexander BE, Liebrand K, Osinga R, van der Geest HG, Admiraal W, Cleutjens JPM, et al. Cell turnover and detritus production in marine sponges from tropical and temperate benthic ecosystems. PLoS One. 2014; 9:e109486.

124. Rix L, de Goeij JM, van Oevelen D, Struck U, Al-Horani FA, Wild C, et al. Reef sponges facilitate the transfer of coral-derived organic matter to their associated fauna via the sponge loop. Mar Ecol Prog Ser. 2018; In press.DOI: https://doi.org/10.3354/meps12444.

125. Azam F, Fenchel T, Field JG, Gray JS, Meyer-Reil LA, Thingstad F. The ecological role of water - column microbes in the sea. Mar Ecol Prog Ser. 1983;10:257-63.

126. de Goeij JM, van Duyl FC. Coral cavities are sinks of dissolved organic carbon (DOC). Limnol Oceanogr. 2007;52:2608-17.

127. Southwell MW, Weisz JB, Martens CS, Lindquist N, Carolina N, Hill C, et al. In situ fluxes of dissolved inorganic nitrogen from the sponge community on Conch reef, Key Largo , Florida. Limnol Oceanogr. 2008;53:986-96.

128. Bayer K, Schmitt S, Hentschel U. Physiology, phylogeny and in situ evidence for bacterial and archaeal nitrifiers in the marine sponge Aplysina aerophoba. Environ Microbiol. 2008;10:2942-55.

129. Taylor MW, Radax R, Steger D, Wagner M. Sponge-associated microorganisms: evolution, ecology, and biotechnological potential. Microbiol Mol Biol Rev. 2007;71:295-347.

130. Richter C, Wunsch M, Rasheed M, Kötter I, Badran M. Endoscopic exploration of Red Sea coral reefs reveals dense populations of cavitydwelling sponges. Nature. 2001;413:726.

131. Slattery M, Gochfeld DJ, Easson CG, O'Donahue LRK. Facilitation of coral reef biodiversity and health by cave sponge communities. Mar Ecol Prog Ser. 2013:476:71-86.

132. Easson CG, Slattery M, Baker DM, Gochfeld DJ. Complex ecological associations: competition and facilitation in a sponge-algal interaction. Mar Ecol Prog Ser. 2014;507:153-67.

133. Yahel G, Whitney F, Reiswig HM, Eerkes-medrano DI, Sally P, Vw C, et al. In situ feeding and metabolism of glass sponges (Hexactinellida, Porifera) studied in a deep temperate fjord with a remotely operated submersible. Limnol Oceanogr. 2007;52:428-40.

134. Archer SK, Stevens JL, Rossi RE, Matterson KO, Layman CA. Abiotic conditions drive significant variability in nutrient processing by a common Caribbean sponge, Ircinia felix. Limnol Oceanogr. 2017;62:1783-93.

135. Zhang F, Blasiak LC, Karolin JO, Powell RJ, Geddes CD, Hill RT. Phosphorus sequestration in the form of polyphosphate by microbial symbionts in marine sponges. Proc Natl Acad Sci U S A. 2015;112(14): 4381-4386.

136. Colman AS. Sponge symbionts and the marine P cycle. Proc Natl Acad Sci U S A. 2015;112:4191-2.

137. Blunt JW, Copp BR, Keyzers RA, Munro MHG, Prinsep MR. Marine natural products. Nat Prod Rep. 2017;34:235-94.

138. Pawlik JR. The chemical ecology of sponges on Caribbean reefs: natural products shape natural systems. Bioscience. 2011;61:888-98.

139. Piel J. Metabolites from symbiotic bacteria. Nat Prod Rep. 2009;26:338-62.

140. McClintock JB, Amsler CD, Baker BJ. Overview of the chemical ecology of benthic marine invertebrates along the Western Antarctic Peninsula. Integr Comp Biol. 2010;50:967-80.

141. Pawlik JR, Chanas B, Toonen RJ, Fenical W. Defenses of Caribbean sponges against predatory fish. I. Chemical deterrency. Mar Ecol Prog Ser. 1995;127:183-94.

142. Rohde S, Nietzer S, Schupp PJ. Prevalence and mechanisms of dynamic chemical defenses in tropical sponges. PLoS One. 2015;10(7):e0132236.

143. Unson MD, Faulkner DJ. Cyanobacterial symbiont biosynthesis of chlorinated metabolites from Dysidea herbacea (Porifera). Experientia. 1993; 49:349-53.

144. Laroche M, Imperatore C, Grozdanov L, Costantino V, Mangoni A, Hentschel $U$, et al. Cellular localisation of secondary metabolites isolated from the Caribbean sponge Plakortis simplex. Mar Biol. 2007;151:1365-73. 
145. Della Sala G, Hochmuth T, Teta R, Costantino V, Mangoni A. Polyketide synthases in the microbiome of the marinesponge Plakortis halichondrioides: a metagenomic update. Mar Drugs. 2014;12:5425-40.

146. Wooster MK, Marty MJ, Pawlik JR. Defense by association: sponge-eating fishes alter the small-scale distribution of Caribbean reef sponges. Mar Ecol Evol Perspect. 2017;38:e12410.

147. Schutte VGW, Byers JE. Variation in a simple trait of mangrove roots governs predator access to, and assemblage composition of, epibiotic sponges. Mar Ecol Prog Ser. 2017;573:15-23.

148. Wulff J. Bottom-up and top-down controls on coral reef sponges: disentangling within-habitat and between-habitat processes. Ecology. 2017; 98:1130-9.

149. Pawlik JR, Loh T-L, McMurray SE, Finelli CM. Sponge communities on Caribbean coral reefs are structured by factors that are top-down, not bottom-up. PLoS One. 2013;8:e62573.

150. Loh TL, Pawlik JR. Chemical defenses and resource trade-offs structure sponge communities on Caribbean coral reefs. Proc Natl Acad Sci U S A. 2014;111:4151-6

151. Tang S-L, Hong M-J, Liao M-H, Jane W-N, Chiang P-W, Chen C-B, et al. Bacteria associated with an encrusting sponge (Terpios hoshinota) and the corals partially covered by the sponge. Environ Microbiol. 2011;13:1179-91.

152. Wang JT, Chen YY, Meng PJ, Sune YH, Hsu CM, Wei KY, et al. Diverse interactions between corals and the coral-killing sponge, Terpios hoshinota (Suberitidae: Hadromerida). Zool Stud. 2012;51:150-9.

153. Thinesh T, Meenatchi R, Pasiyappazham R, Jose PA, Selvan M, Kiran GS, et al. Short-term in situ shading effectively mitigates linear progression of coralkilling sponge Terpios hoshinota. PLoS One. 2017;12:e0182365.

154. Teruya T, Nakagawa S, Koyama T, Arimoto H, Kita M, Uemura D. Nakiterpiosin and nakiterpiosinone, novel cytotoxic C-nor-D-homosteroids from the Okinawan sponge Terpios hoshinota. Tetrahedron. 2004;60:6989-93.

155. Wang J-T, Hsu C-M, Kuo C-Y, Meng P-J, Kao S-J, Chen CA. Physiological outperformance at the morphologically-transformed edge of the cyanobacteriosponge Terpios hoshinota (Suberitidae: Hadromerida) when confronting opponent corals. PLoS One. 2015;10:e0131509.

156. Shi Q, Liu GH, Yan HQ, Zhang HL. Black disease (Terpios hoshinota): a probable cause for the rapid coral mortality at the northern reef of Yongxing Island in the South China Sea. Ambio. 2012;41(5):446-55.

157. Bryan PG. Growth rate, toxicity, and distribution of the encrusting sponge Terpios sp. (Hadromerida: Suberitidae) in Guam. Micronesica. 1973;9:238-42.

158. Fan L, Liu M, Simister R, Webster NS, Thomas T. Marine microbial symbiosis heats up: the phylogenetic and functional response of a sponge holobiont to thermal stress. ISME J. 2013;7:991-1002.

159. Rix L, Bednarz VN, Cardini U, van Hoytema N, Al-Horani FA, Wild C, et al. Seasonality in dinitrogen fixation and primary productivity by coral reef framework substrates from the northern Red Sea. Mar Ecol Prog Ser. 2015; 533:79-92.

160. Freeman CJ, Baker DM, Easson CG, Thacker RW. Shifts in sponge-microbe mutualisms across an experimental irradiance gradient. Mar Ecol Prog Ser. 2015;526:41-53

161. Slattery M, Gochfeld DJ, Diaz MC, Thacker RW, Lesser MP. Variability in chemical defense across a shallow to mesophotic depth gradient in the Caribbean sponge Plakortis angulospiculatus. Coral Reefs. 2016;35: $11-22$.

162. Moya A, Ferrer M. Functional redundancy- induced stability of gut microbiota subjected to disturbance. Trends Microbiol. 2016;24:402-13.

163. Cho I, Blaser MJ. The human microbiome: at the interface of health and disease. Nat Rev Genet. 2012;13:260-70.

164. Egan S, Gardiner M. Microbial dysbiosis: rethinking disease in marine ecosystems. Front Microbiol. 2016;7:991.

165. Webster NS, Reusch TBH. Microbial contributions to the persistence of coral reefs. ISME J. 2017;11:2167-74.

166. Waters CN, Zalasiewicz J, Summerhayes C, Barnosky AD, Poirier C, Galuszka A, et al. The Anthropocene is functionally and stratigraphically distinct from the Holocene. Science. 2016;351:137-48.

167. Simister R, Taylor MW, Tsai P, Webster N. Sponge-microbe associations survive high nutrients and temperatures. PLoS One. 2012;7:e52220.

168. Strand R, Whalan S, Webster NS, Kutti T, Fang JKH, Luter HM, et al. The response of a boreal deep-sea sponge holobiont to acute thermal stress. Sci Rep. 2017;7:1660

169. Luter HM, Gibb K, Webster NS. Eutrophication has no short-term effect on the Cymbastela stipitata holobiont. Front Microbiol. 2014;5:216.
170. Pineda M-C, Strehlow B, Sternel M, Duckworth A, Jones R, Webster NS. Effects of suspended sediments on the sponge holobiont with implications for dredging management. Sci Rep. 2017;7:4925.

171. López-Legentil S, Song B, McMurray SE, Pawlik JR. Bleaching and stress in coral reef ecosystems: hsp70 expression by the giant barrel sponge Xestospongia muta. Mol Ecol. 2008;17:1840-9.

172. Webster N, Pantile R, Botté E, Abdo D, Andreakis N, Whalan S. A complex life cycle in a warming planet: gene expression in thermally stressed sponges. Mol. Ecol. 2013;22(7):1854-68.

173. Luter HM, Whalan S, Webster NS. Thermal and sedimentation stress are unlikely causes of brown spot syndrome in the coral reef sponge, lanthella basta. PLoS One. 2012;7:e39779.

174. Lesser MP, Fiore C, Slattery M, Zaneveld J. Climate change stressors destabilize the microbiome of the Caribbean barrel sponge, Xestospongia muta. J Exp Mar Bio Ecol. 2016:475:11-8.

175. Zaneveld JR, McMinds R, Vega TR. Stress and stability: applying the Anna Karenina principle to animal microbiomes. Nat Microbiol. 2017:2:17121.

176. Tian R, Wang Y, Bougouffa S, Gao Z, Cai L, Zhang W, et al. Effect of copper treatment on the composition and function of the bacterial community in the sponge Haliclona cymaeformis. MBio. 2014;5:e01980-14.

177. Pinzón JH, Kamel B, Burge CA, Harvell CD, Medina M, Weil E, et al. Whole transcriptome analysis reveals changes in expression of immune-related genes during and after bleaching in a reef-building coral. Open Sci. 2015; 2(4):140214.

178. Liu S, Shi W, Guo C, Zhao X, Han Y, Peng C, et al. Ocean acidification weakens the immune response of blood clam through hampering the NF-kappa $B$ and toll-like receptor pathways. Fish Shellfish Immunol. 2016;54:322-7.

179. Ghanbari M, Kneifel W, Domig KJ. A new view of the fish gut microbiome: advances from next-generation sequencing. Aquaculture. 2015:448:464-75

180. Pantile R, Webster N. Strict thermal threshold identified by quantitative PCR in the sponge Rhopaloeides odorabile. Mar Ecol Prog Ser. 2011:431:97-105.

181. Guzman C, Conaco C. Gene expression dynamics accompanying the sponge thermal stress response. PLoS One. 2016;11:e0165368.

182. Simister R, Taylor MW, Tsai P, Fan L, Bruxner TJ, Crowe ML, et al. Therma stress responses in the bacterial biosphere of the Great Barrier Reef sponge, Rhopaloeides odorabile. Environ Microbiol. 2012;14:3232-46.

183. Bennett HM, Altenrath C, Woods L, Davy SK. Interactive effects of temperature and $\mathrm{pCO} 2$ on sponges: from the cradle to the grave. Glob Chang Biol. 2017:23:2031-46.

184. Palmer C V., McGinty ES, Cummings DJ, Smith SM, Bartels E, Mydlarz LD. Patterns of coral ecological immunology: variation in the responses of Caribbean corals to elevated temperature and a pathogen elicitor. J Exp Biol. 2011;214(24):4240-9.

185. Burge CA, Mouchka ME, Harvell CD, Roberts S. Immune response of the Caribbean sea fan, Gorgonia ventalina, exposed to an Aplanochytrium parasite as revealed by transcriptome sequencing. Front Physiol. 2013;4:180.

186. van de Water JAJM, Lamb JB, Heron SF. Temporal patterns in innate immunity parameters in reef building corals and linkages with local climatic conditions. Ecosphere. 2016;7:e01505

187. Bourne DG, Garren M, Work TM, Rosenberg E, Smith GW, Harvell CD. Microbial disease and the coral holobiont. Trends Microbiol. 2009;17:554-62.

188. Burge CA, Mark Eakin C, Friedman CS, Froelich B, Hershberger PK, Hofmann $\mathrm{EE}$, et al. Climate change influences on marine infectious diseases: implications for management and society. Annu Rev Mar Sci. 2014:6:249-77.

189. Webster NS. Sponge disease: a global threat? Environ Microbiol. 2007;9: 1363-75.

190. Garrabou J, Coma R, Bensoussan N, Bally M, Chevaldonné P, Cigliano M, et al. Mass mortality in northwestern Mediterranean rocky benthic communities: effects of the 2003 heat wave. Glob Chang Biol. 2009;15: 1090-103.

191. Coma R, Ribes M, Serrano E, Jiménez E, Salat J, Pascual J. Global warmingenhanced stratification and mass mortality events in the Mediterranean. Proc Natl Acad Sci U S A. 2009:106:6176-81.

192. Lesser MP, Bythell JC, Gates RD, Johnstone RW, Hoegh-Guldberg O. Are infectious diseases really killing corals? Alternative interpretations of the experimental and ecological data. J Exp Mar Bio Ecol. 2007; 346:36-44.

193. Bourne DG, Morrow KM, Webster NS. Insights into the coral microbiome: underpinning the health and resilience of reef ecosystems. Annu Rev Microbiol. 2016;70:317-40. 
194. Cebrián E, Uriz MJ, Garrabou J, Ballesteros E. Sponge mass mortalities in a warming Mediterranean Sea: are cyanobacteria-harboring species worse off? PLoS One. 2011;6:e20211.

195. Maldonado M, Sánchez-Tocino L, Navarro C. Recurrent disease outbreaks in corneous demosponges of the genus Ircinia: epidemic incidence and defense mechanisms. Mar Biol. 2010;157:1577-90.

196. Luter HM, Whalan S, Webster NS. Prevalence of tissue necrosis and brown spot lesions in a common marine sponge. Mar Freshw Res. 2010;61:484-9.

197. Luter HM, Whalan S, Webster NS. Exploring the role of microorganisms in the disease-like syndrome affecting the sponge lanthella basta. Appl Environ Microbiol. 2010;76:5736-44.

198. Angermeier H, Kamke J, Abdelmohsen UR, Krohne G, Pawlik JR, Lindquist $\mathrm{NL}$, et al. The pathology of sponge orange band disease affecting the Caribbean barrel sponge Xestospongia muta. FEMS Microbiol Ecol. 2011;75 218-30.

199. Angermeier H, Glöckner V, Pawlik JR, Lindquist NL, Hentschel U. Sponge white patch disease affecting the Caribbean sponge Amphimedon compressa. Dis Aquat Org. 2012;99:95-102.

200. Webster NS, Negri AP, Webb Rl, Hill RT. A spongin-boring a -proteobacterium is the etiological agent of disease in the great barrier reef sponge Rhopaloeides odorabile. Mar Ecol Prog Ser. 2002;232:305-9.

201. Choudhury JD, Pramanik A, Webster NS, Llewellyn LE, Gachhui R, Mukherjee J. The pathogen of the great barrier reef sponge Rhopaloeides odorabile is a new strain of Pseudoalteromonas agarivorans containing abundant and diverse virulence-related genes. Mar Biotechnol. 2015;17:463-78.

202. Blanquer A, Uriz MJ, Cebrian E, Galand PE. Snapshot of a bacterial microbiome shift during the early symptoms of a massive sponge die-off in the western Mediterranean. Front Microbiol. 2016;7:752.

203. Webster NS, Xavier JR, Freckelton M, Motti CA, Cobb R. Shifts in microbial and chemical patterns within the marine sponge Aplysina aerophoba during a disease outbreak. Environ Microbiol. 2008;10:3366-76.

204. Luter HM, Bannister RJ, Whalan S, Kutti T, Pineda M, Webster NS. Microbiome analysis of a disease affecting the deep-sea sponge Geodia barretti. FEMS Microbiol Ecol. 2017;93:1-6.

205. Gao Z-M, Wang Y, Tian R-M, Lee OO, Wong YH, Batang ZB, et al. Pyrosequencing revealed shifts of prokaryotic communities between healthy and disease-like tissues of the Red Sea sponge Crella cyathophora. PeerJ. 2015:3:e890.

206. Deignan LK, Pawlik JR, Erwin PM. Agelas wasting syndrome alters prokaryotic symbiont communities of the Caribbean brown tube sponge, Agelas tubulata. Microb Ecol; 2018. https://doi.org/10.1007/s00248-017-1135-3.

207. Sweet MJ, Bulling MT. On the importance of the microbiome and pathobiome in coral health and disease. Front Mar Sci. 2017:4:9.

208. Mera H, Bourne DG. Disentangling causation: complex roles of coralassociated microorganisms in disease. Environ Microbiol. 2018;20:431-49.

209. Maldonado M, Young CM. Limits on the bathymetric distribution of keratose sponges: a field test in deep water. Mar Ecol Prog Ser. 1998;174:123-39.

210. Reshef L, Koren O, Loya Y, Zilber-Rosenberg I, Rosenberg E. The coral probiotic hypothesis. Environ Microbiol. 2006:8:2068-73.

211. Putnam HM, Barott KL, Ainsworth TD, Gates RD. The vulnerability and resilience of reef-building corals. Curr Biol Elsevier Ltd. 2017;27:528-40.

212. Rosenberg E, Koren O, Reshef L, Efrony R, Zilber-Rosenberg I. The role of microorganisms in coral health, disease and evolution. Nat Rev Microbiol. 2007:5:355-62

213. Ribes M, Calvo E, Movilla J, Logares R, Coma R, Pelejero C. Restructuring of the sponge microbiome favors tolerance to ocean acidification. Environ. Microbiol. Rep. 2016;8(4):536-44.

214. Ziegler M, Seneca FO, Yum LK, Palumbi SR, Voolstra CR. Bacterial community dynamics are linked to patterns of coral heat tolerance. Nat Commun. 2017; 8:14213.

215. Bell JJ, Davy SK, Jones T, Taylor MW, Webster NS. Could some coral reefs become sponge reefs as our climate changes? Glob Chang Biol. 2013;19:2613-24.

216. Biggerstaff A, Jompa J, Bell JJ. Increasing benthic dominance of the phototrophic sponge Lamellodysidea herbacea on a sedimented reef within the coral triangle. Mar Biol. 2017;164:220.

217. Powell A, Smith DJ, Hepburn LJ, Jones T, Berman J, Jompa J, et al. Reduced diversity and high sponge abundance on a sedimented indo-Pacific reef system: implications for future changes in environmental quality. PLoS One. 2014;9:e85253

218. Bell JJ, Mcgrath E, Biggerstaff A, Bates T, Cárdenas CA, Bennett H. Global conservation status of sponges. Conserv Biol. 2015;29:42-53.
219. Wulff JL. Rapid diversity and abundance decline in a Caribbean coral reef sponge community. Biol Conserv. 2006;127:167-76.

220. Calvo E, Simó R, Coma R, Ribes M, Pascual J, Sabatés A, et al. Effects of climate change on Mediterranean marine ecosystems: the case of the Catalan Sea. Clim Res. 2011;50:1-29.

221. Webster NS, Luter HM, Soo RM, Botté ES, Simister RL, Abdo D, et al. Same, same but different: symbiotic bacterial associations in GBR sponges. Front Microbiol. 2012;3:444.

222. Glasl B, Webster NS, Bourne DG. Microbial indicators as a diagnostic tool for assessing water quality and climate stress in coral reef ecosystems. Mar Biol. 2017;164:91

223. Semenza JC, Trinanes J, Lohr W, Sudre B, Martinez-urtaza J, Nichols GL. Environmental suitability of Vibrio infections in a warming climate: an early warning system. Environ Health Perspect. 2017;125(10).

224. Faust K, Lahti L, Gonze D, de Vos WM, Raes J. Metagenomics meets time series analysis: unraveling microbial community dynamics. Curr Opin Microbiol. 2015;25:56-66

225. Hentschel U, Fieseler L, Wehrl M, Gernert C, Steinert M, Hacker J, et al. Microbial diversity of marine sponges. In: Mueller WEG (eds.) Sponges (Porifera). Progress in molecular and subcellular biology. Springer Berlin Heidelberg. 2003;59-88. https://doi.org/10.1007/978-3-642-55519-0_3.

226. Gloeckner V, Wehrl M, Moitinho-Silva L, Gernert C, Schupp P, Pawlik JR, et al. The HMA-LMA dichotomy revisited: an electron microscopical survey of 56 sponge species. Biol Bull. 2014;227:78-88.

227. Moitinho-Silva L, Steinert G, Nielsen S, Hardoim CCP, Wu Y-C, McCormack $G P$, et al. Predicting the HMA-LMA status in marine sponges by machine learning. Front Microbiol. 2017;8:752.

228. Easson CG, Thacker RW. Phylogenetic signal in the community structure of host-specific microbiomes of tropical marine sponges. Front Microbiol. 2014; 5:532.

229. Weisz JB, Hentschel U, Lindquist N, Martens CS. Linking abundance and diversity of sponge-associated microbial communities to metabolic differences in host sponges. Mar Biol. 2007;152:475-83.

230. Poppell E, Weisz J, Spicer L, Massaro A, Hill A, Hill M. Sponge heterotrophic capacity and bacterial community structure in high- and low-microbial abundance sponges. Mar. Ecol. 2013;35(4):414-24.

231. Webster NS, Botté ES, Soo RM, Whalan S. The larval sponge holobiont exhibits high thermal tolerance. Environ Microbiol Rep. 2011;3:756-62.

232. Webster NS, Cobb RE, Negri AP. Temperature thresholds for bacterial symbiosis with a sponge. ISME J. 2008;2:830-42.

233. Pita L, Erwin PM, Turon X, López-Legentil S. Till death do us part: stable sponge-bacteria associations under thermal and food shortage stresses. PLoS One. 2013;8:e80307.

234. López-Legentil S, Erwin PM, Pawlik JR, Song B. Effects of sponge bleaching on ammonia-oxidizing archaea: distribution and relative expression of ammonia monooxygenase genes associated with the barrel sponge Xestospongia muta. Microb Ecol. 2010;60:561-71.

235. Lemoine N, Buell N, Hill A, Hill M. Assessing the utility of sponge microbia symbiont communities as models to study global climate change: a case study with Halichondria bowerbanki. Porifera Res Biodivers Innov Sustain Série Livros. 2007;28:239-46.

236. Webster NS, Webb RI, Ridd MJ, Hill RT, Negri AP. The effects of copper on the microbial community of a coral reef sponge. Environ Microbiol. 2001;3:19-31.

237. Langille MGI, Zaneveld J, Caporaso JG, McDonald D, Knights D, Reyes JA, et al. Predictive functional profiling of microbial communities using $16 \mathrm{~S}$ rRNA marker gene sequences. Nat Biotechnol. 2013;31:814-21. 